\title{
25. LATE MIOCENE TO EARLIEST PLIOCENE (9.8-4.5 MA) PALEOCEANOGRAPHY OF THE SUBANTARCTIC SOUTHEAST ATLANTIC: STABLE ISOTOPIC, SEDIMENTOLOGIC, AND MICROFOSSIL EVIDENCE ${ }^{1}$
}

\author{
Daniel W. Müller, ${ }^{2}$ David A. Hodell, ${ }^{2}$ and Paul F. Ciesielski ${ }^{2}$
}

\begin{abstract}
Carbonate stratigraphy and stable isotopic ratios of benthic and planktonic foraminifers were used to study paleoceanographic changes that occurred during the late Miocene to earliest Pliocene in the subantarctic South Atlantic, between 9.8 and $4.5 \mathrm{Ma}$ in ODP Hole 704B on the Meteor Rise $\left(47^{\circ} \mathrm{S}, 7^{\circ} \mathrm{E} ; 2532 \mathrm{~m}\right.$ water depth).

During the late Miocene, between 9.8 and $6.4 \mathrm{Ma}$, carbonate content was high with little variability (generally $84.5 \% \pm 10 \%$ ), with sustained productivity dominated by foraminifers and calcareous nannoplankton in surface waters north of the Subantarctic Front. Decreased carbonate $(40 \%)$, along with first significant occurrence of biogenic opal, occurred between 8.45 and $8.2 \mathrm{Ma}$. The first signals of increased cooling occurred between 8.8 and 8.0 Ma.

The interval from 6.3 to $4.5 \mathrm{Ma}$ represents low carbonate values with high variability $(61.7 \% \pm 17 \%)$, suggesting markedly fluctuating conditions in the production and/or dissolution of carbonate. The onset of this interval in Hole 704B is marked by a decrease in carbonate values and a well-defined $0.85 \%$ decrease in $\delta^{13} \mathrm{C}$ values of both planktonic and benthic foraminifers between 6.4 and $6.0 \mathrm{Ma}$, correlated to the Chron C3AR (upper reversed of Chron 6) "carbon shift." The interval of the carbon shift $(6.4$ to $6.0 \mathrm{Ma})$ is characterized by decreasing $\delta^{18} \mathrm{O}$ values, anomalously low $\delta^{18} \mathrm{O}$ minima in planktonic foraminifers, and intervals dominated by temperate and low-latitude diatom and silicoflagellate assemblages, suggesting warm interglacial conditions with brief events of extreme warming or low salinity in the subantarctic South Atlantic. An anomalously low planktonic $\delta^{18} \mathrm{O}$ minimum at 6.15 $\mathrm{Ma}$ in Hole 704B is correlated with the deposition of the laminated organic-rich Neobrunia ooze found in Hole 701 during this leg and the Ethmodiscus ooze drilled at DSDP Site 520 on Leg 73. Suboxic bottom water may have formed in response to a meltwater lid that temporarily halted the production of Antarctic Bottom Water during the rapid deglaciation events that were occurring in West Antarctica.

The benthic $\delta^{18} \mathrm{O}$ record displays a strong glacial interval between 5.8 and $5.4 \mathrm{Ma}$, which is coincident with the time of a major increase in an upwelling diatom assemblage between 6.0 and 5.4 Ma. The earliest Gilbert Chron (5.35 to $4.77 \mathrm{Ma}$ ) was marked by an intense carbonate dissolution event and low surface productivity. This dissolution event, recognized globally, ended abruptly near the base of the Thvera Subchron at $4.8 \mathrm{Ma}$ when carbonate values increased to $75.3 \% \pm 5.2 \%$. The low carbonate content and highly variable surface water conditions between 6.3 and 4.8 $\mathrm{Ma}$ are time equivalent to the Messinian Stage in the Mediterranean, suggesting a possible link between the Messinian salinity crisis and the Southern Ocean during the latest Miocene.
\end{abstract}

\section{INTRODUCTION}

The late Miocene (10 to $6.5 \mathrm{Ma}$ ) was a time of relatively cool climate that followed a major buildup of ice on East Antarctica during the middle Miocene (Shackleton and Kennett, 1975). In the latest Miocene, between about 6.3 and 5 $\mathrm{Ma}$, major climatic and paleoceanographic events occurred, including the Chron C3AR carbon shift, a worldwide regression, shoaling of the carbonate compensation depth (CCD) and lysocline, cooling and ice volume expansion, and the Messinian salinity crisis.

The recovery of a nearly complete late Miocene carbonatebearing sequence from Hole 704B of Ocean Drilling Program (ODP) Leg 114 provides an opportunity to study late Miocene paleoceanographic change in the subantarctic sector of the South Atlantic. Here we report on preliminary stable isotopic and carbonate results from the western flank of the Meteor Rise. The relatively high-latitude position of Site $704\left(46^{\circ} 52^{\prime} \mathrm{S}\right.$, $7^{\circ} 25^{\prime} \mathrm{E}$ ), its close proximity to the Polar Frontal Zone (PFZ) (Fig. 1), and its intermediate water depth (2532 m) make it well

\footnotetext{
${ }^{1}$ Ciesielski, P. F., Kristoffersen, Y., et al., 1991. Proc. ODP, Sci. Results, 114: College Station, TX (Ocean Drilling Program).

2 Department of Geology, University of Florida, Gainesville, FL 32611 (Müller, present address: Geologisches Institut, Swiss Federal Institute of Technology, ETH-Zentrum, 8092 Zürich, Switzerland).
}

suited for paleoceanographic study. Site 704 lies today in upper deep waters that are a mixture of Circumpolar Deep Water (CPDW) and North Atlantic Deep Water (NADW). The only other carbonate-bearing late Miocene sequence that exists within subantarctic waters is at Deep Sea Drilling Project (DSDP) Site 281 in the southwest Pacific $\left(47^{\circ} \mathrm{S}, 147^{\circ} \mathrm{E}\right)$. Unfortunately, this site suffers from rotary-drilling disturbance, incomplete core recovery, and the lack of a precise biomagnetostratigraphic framework.

The paleoceanographic results of this study will be discussed in connection with the Messinian events of the Mediterranean Sea, as well as sea-level, circulation, and Antarctic climate changes.

\section{METHODS AND PROCEDURES}

\section{Carbonate and Stable Isotopic Analyses}

The methods of carbonate determinations are discussed in Froelich et al. (this volume). For isotopic analyses, sinistrallycoiled specimens of Neogloboquadrina pachyderma were picked from the 150-250- $\mu \mathrm{m}$ size fraction. Where possible, monospecific or monogeneric assemblages-mainly Cibicidoides kullenbergi-were picked for the benthic record. Where this species was absent, we analyzed Uvigerina spp., Globocassidulina subglobosa, or Laticarinina pauperata. Foraminiferal tests were checked for diagenetic calcite and ultrasonically cleaned. 


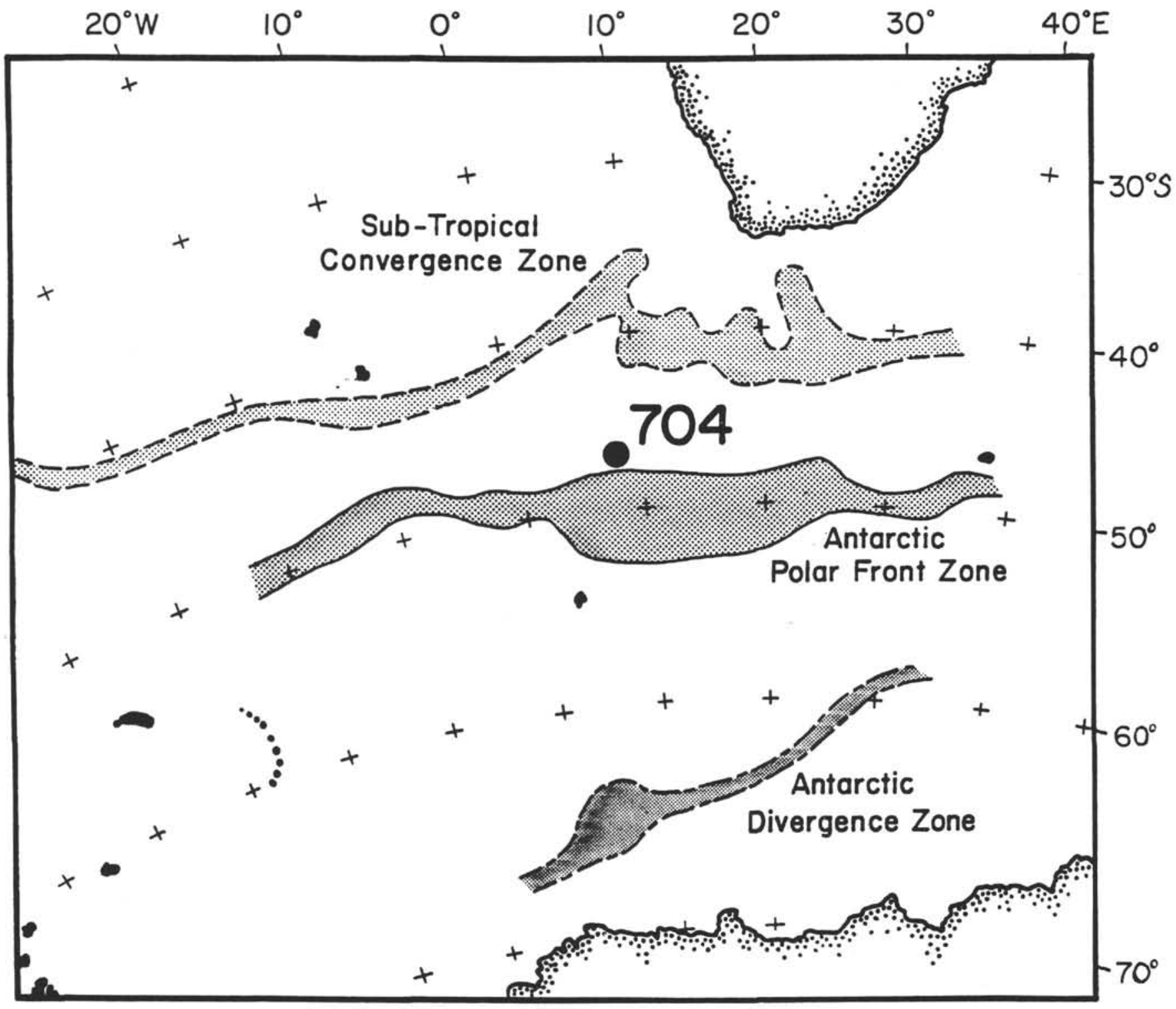

Figure 1. The position of ODP Site 704 in the eastern subantarctic South Atlantic relative to major hydrographic fronts (modified after Lutjeharms, 1985).

Isotopic methods are the same as described in Hodell et al. (1989). All results are reported in standard delta notation and corrected to PDB. Analytical precision, based upon routine analysis of a powdered carbonate standard (Carrara Marble), was \pm 0.13 for $\delta^{18} \mathrm{O}$ and \pm 0.04 for $\delta^{13} \mathrm{C}$ ( 1 sigma). All analytical values are given in Tables 1 and 2 .

In order to account for species-dependent departures from isotopic ratios of $C$. kullenbergi, we corrected benthic foraminifer measurements of various species using the correction factors suggested by Shackleton et al. (1984) and Woodruff et al. (1980) (Table 3). No correction was applied for the oxygen and carbon isotopic disequilibrium of $C$. kullenbergi and $N$. pachyderma to the predicted $\delta^{18} \mathrm{O}$ and $\delta^{13} \mathrm{C}$ of calcite in equilibrium with $\Sigma \mathrm{CO}_{2}$ of seawater.

Sampling frequency for isotopic analyses varies markedly from 6000 to $100,000 \mathrm{yr}$ because of variation in the sedimentation rate and degree of preservation of the foraminifers. As a result, the isotopic record is strongly biased toward intervals of high carbonate content.
Our sampling frequency for carbonate analyses approaches a $\sim 4000$-yr frequency only in a few intervals (Table 4), and thus, the possibility of data bias cannot be excluded.

\section{Stratigraphic Framework}

Most of the late Miocene age determinations are based on the magnetostratigraphy with absolute age assignments after Berggren et al. (1985). Paleomagnetic boundaries were initially determined by Hailwood and Clement (this volume). Correlation of biostratigraphic markers to the geomagnetic polarity time scale supports the correlation of anomaly 5 to Chron C5N (Table 5). Sedimentation rates range from 92 to $4.7 \mathrm{~m} / \mathrm{m} . \mathrm{y}$. Sedimentation rates are low or decrease between 7.28 and $6.78 \mathrm{Ma}$ and between 5.35 and $4.47 \mathrm{Ma}$ (Table 4).

\section{Biostratigraphic Analysis}

The Gilbert Chron, as well as Chrons C3AN, C3AR, and $\mathrm{C} 5 \mathrm{~N}$, is particularly well constrained by the biostratigraphic data and the carbon shift. Biostratigraphic control for the 
Table 1. Stable isotopic measurements of left-coiled Neogloboquadrina pachyderma from Cores 114-704B-24X through 114-704B-41X.

\begin{tabular}{|c|c|c|c|c|c|c|c|}
\hline $\begin{array}{l}\text { Depth } \\
\text { (mbsf) }\end{array}$ & $\begin{array}{c}\text { Age } \\
(\mathrm{m} . \mathrm{y} .)\end{array}$ & $\begin{array}{c}\delta^{13} \mathrm{C} \\
(\% \text { PDB })\end{array}$ & $\begin{array}{c}\delta^{18} \mathrm{O} \\
(\% \circ \mathrm{PDB})\end{array}$ & $\begin{array}{l}\text { Depth } \\
\text { (mbsf) }\end{array}$ & $\begin{array}{c}\text { Age } \\
(\mathrm{m} . \mathrm{y} .)\end{array}$ & $\begin{array}{c}\delta^{13} \mathrm{C} \\
(\% \circ \mathrm{PDB})\end{array}$ & $\begin{array}{c}\delta^{18} \mathrm{O} \\
(\% \circ \mathrm{PDB})\end{array}$ \\
\hline 214.21 & 4.49 & 0.66 & 1.47 & 256.11 & 6.47 & 1.42 & 1.71 \\
\hline 214.51 & 4.51 & 0.98 & 1.54 & 257.61 & 6.51 & 1.20 & 1.71 \\
\hline 215.11 & 4.56 & 0.70 & 1.91 & 259.11 & 6.66 & 1.86 & 1.74 \\
\hline 215.71 & 4.59 & 0.76 & 1.72 & 261.71 & 6.74 & 1.57 & 1.90 \\
\hline 216.01 & 4.60 & 0.76 & 1.95 & 262.61 & 6.75 & 1.52 & 1.73 \\
\hline 216.61 & 4.63 & 0.78 & 2.17 & 264.11 & 6.77 & 1.51 & 1.81 \\
\hline 217.21 & 4.66 & 1.28 & 2.38 & 268.61 & 7.31 & 1.59 & 1.79 \\
\hline 217.51 & 4.68 & 1.02 & 2.02 & 272.11 & 7.37 & 1.61 & 1.89 \\
\hline 218.11 & 4.71 & 0.83 & 2.12 & 275.11 & 7.41 & 1.40 & 2.11 \\
\hline 219.91 & 4.82 & 0.33 & 1.33 & $28 \quad 0.71$ & 7.59 & 1.48 & 1.67 \\
\hline 222.61 & 5.13 & 0.72 & 1.74 & 282.21 & 7.64 & 1.63 & 1.81 \\
\hline 223.21 & 5.19 & 0.58 & 1.25 & 283.71 & 7.69 & 1.46 & 2.01 \\
\hline 223.41 & 5.22 & 1.06 & 1.84 & 284.61 & 7.72 & 1.63 & 1.35 \\
\hline 223.60 & 5.24 & 0.54 & 1.74 & 286.11 & 7.77 & 1.63 & 1.82 \\
\hline 223.71 & 5.25 & 0.25 & 1.68 & 288.21 & 7.84 & 2.15 & 1.29 \\
\hline 224.91 & 5.36 & 0.71 & 1.74 & 289.11 & 7.87 & 1.47 & 1.93 \\
\hline 225.10 & 5.36 & 0.27 & 1.74 & 291.70 & 7.92 & 1.51 & 1.72 \\
\hline 226.41 & 5.40 & 0.58 & 1.90 & 293.21 & 7.93 & 1.48 & 1.60 \\
\hline 229.11 & 5.48 & 0.62 & 0.98 & 297.71 & 7.98 & 1.37 & 1.89 \\
\hline 229.41 & 5.49 & 0.91 & 1.53 & 299.21 & 7.99 & 1.23 & 1.82 \\
\hline 229.60 & 5.49 & 0.62 & 2.00 & 299.71 & 8.00 & 2.07 & 1.75 \\
\hline 230.29 & 5.51 & 0.69 & 2.01 & 300.61 & 8.01 & 1.93 & 1.79 \\
\hline 230.91 & 5.53 & 0.96 & 0.69 & 301.21 & 8.02 & 1.83 & 1.85 \\
\hline 231.10 & 5.54 & 0.66 & 1.71 & 302.71 & 8.04 & 1.24 & 1.52 \\
\hline 231.21 & 5.54 & 0.43 & 0.90 & 306.61 & 8.08 & 1.59 & 1.74 \\
\hline 232.41 & 5.60 & 0.86 & 2.06 & 307.21 & 8.09 & 1.34 & 1.89 \\
\hline 232.60 & 5.61 & 0.26 & 2.13 & 308.11 & 8.10 & 1.19 & 1.82 \\
\hline 233.21 & 5.64 & 0.60 & 1.07 & 310.71 & 8.13 & 2.00 & 1.45 \\
\hline 234.71 & 5.70 & 0.95 & 1.44 & 312.21 & 8.14 & 2.25 & 1.89 \\
\hline 235.01 & 5.71 & 0.67 & 1.07 & 313.71 & 8.16 & 1.83 & 1.86 \\
\hline 235.51 & 5.72 & 0.75 & 1.62 & 315.21 & 8.18 & 2.12 & 1.51 \\
\hline 235.61 & 5.73 & 0.68 & 1.56 & 318.21 & 8.21 & 1.36 & 2.03 \\
\hline 235.91 & 5.73 & 1.40 & -0.20 & 318.71 & 8.22 & 1.51 & 1.79 \\
\hline 237.11 & 5.77 & 0.71 & 0.85 & 320.21 & 8.27 & 1.43 & 1.33 \\
\hline 238.51 & 5.81 & 0.04 & 1.85 & 323.21 & 8.38 & 1.15 & 1.80 \\
\hline 238.91 & 5.82 & 0.96 & 1.36 & 324.71 & 8.43 & 1.40 & 1.97 \\
\hline 239.21 & 5.83 & 0.29 & 1.43 & 326.21 & 8.47 & 1.46 & 2.02 \\
\hline 240.41 & 5.86 & 0.47 & 1.28 & 327.71 & 8.51 & 1.40 & 1.77 \\
\hline 243.91 & 6.00 & 0.45 & 1.24 & 328.21 & 8.52 & 1.39 & 1.72 \\
\hline 245.11 & 6.05 & 0.61 & 1.78 & 329.71 & 8.55 & 1.46 & 1.90 \\
\hline 246.07 & 6.10 & 0.74 & 1.90 & 331.21 & 8.58 & 1.27 & 1.08 \\
\hline 246.61 & 6.12 & 1.02 & 1.56 & 337.71 & 8.70 & 1.78 & 1.64 \\
\hline 246.85 & 6.13 & 1.04 & 1.45 & 339.21 & 8.73 & 1.44 & 1.92 \\
\hline 247.21 & 6.15 & 0.73 & 0.33 & 340.71 & 8.76 & 1.50 & 1.77 \\
\hline 247.81 & 6.17 & 1.01 & 0.48 & 356.71 & 9.15 & 1.70 & 1.39 \\
\hline 252.20 & 6.37 & 1.74 & 1.71 & 358.21 & 9.18 & 1.51 & 1.60 \\
\hline 253.11 & 6.39 & 1.87 & 1.66 & 359.71 & 9.22 & 1.57 & 1.48 \\
\hline 253.11 & 6.39 & 1.98 & 1.77 & 361.21 & 9.26 & 1.85 & 1.65 \\
\hline 253.70 & 6.41 & 1.55 & 1.33 & 364.21 & 9.33 & 1.71 & 1.43 \\
\hline 254.61 & 6.43 & 1.45 & 1.70 & 370.71 & 9.48 & 1.17 & 1.79 \\
\hline
\end{tabular}

interpretation of the late Miocene-earliest Pliocene is based upon diatoms, radiolarians, and, to a lesser degree, planktonic foraminifers (Table 5). The base of the Sidufjall Subchron is marked by the last-appearance datums of the diatom $D$. hustedtii and the radiolarian S. peregrina and the Gilbert/ C3AN Chron boundary, which is confidently placed just below the first-appearance datums of the planktonic foraminifer $G$. sphericomiozea and the diatom T. oestrupii. The top of the carbon shift occurs just below the Chron C3AR/C3AN boundary and its base is within the upper part of Subchron C3AR.6-C3AR.75. The Chron C5R/C5N boundary is also well constrained by a number of datums immediately above, within, and below the long normal polarity interval of C5N.

It should be noted that biostratigraphic control for the interval between the base of Chron C3AR (6.7 Ma) and Chron C $5 \mathrm{~N}(8.92 \mathrm{Ma})$ is limited because no complete antarctic or subantarctic section of this interval has been recovered with a paleomagnetic record. Nevertheless, a distinct succession of diatom and radiolarian events is recognized in this interval, at DSDP Site 594 and, to some extent, DSDP Site 513 and ODP Site 701. Estimated ages for these datum levels (Table 5) are consistent with our paleomagnetic interpretation and the limited calcareous nannofossil data interpretation from Site 594. Some age estimates of radiolarian datums (e.g., those of Weaver, 1983) have been revised and differ from Ciesielski, Kristoffersen, et al. (1988). For a more thorough discussion see the Table 5 footnotes and the pertinent biostratigraphic chapters in this volume.

The range of the diatom species Cosmiodiscus insignis $\mathrm{f}$. triangula should be noted as it is crucial to our interpretation of subantarctic conditions during the carbon shift. This species occurs throughout a nearly monospecific (Neobrunia) diatom ooze at Site 701, which is mentioned in detail in the discussion. Quantitative studies of the same species from Site 704 (Fenner, this volume) revealed only isolated, minor occurrences in the interval between 7.98 and $7.93 \mathrm{Ma}$ and near the C3AN/Gilbert boundary $(5.38 \mathrm{Ma})$. The principal range and acme (at times $30 \%$ of assemblage) is nearly equivalent to the carbon shift interval, as its base is just above the base of the carbon shift and the Chron C3AR (Chron 6) boundary. The top of the acme is immediately above the top of the carbon shift and the Chron C3AR/C3AN boundary. The Site 701 Neobrunia ooze is bracketed by the C3AR/C3AN boundary $(5.89 \mathrm{Ma})$ above and a disconformity below; however, based upon the presence of $C$. triangula $\mathrm{f}$. triangula throughout, the nearly monospecific ooze is correlative to its acme in Hole 704B (6.42-5.91 Ma) and the carbon shift.

\section{RESULTS}

\section{Carbonate Stratigraphy}

Based on changes in percent carbonate, mean carbonate, and accumulation rate values (Fig. 2), the late Miocene carbonate record can be divided into two distinct intervals of variability. Interval 1, between 9.8 and $6.4 \mathrm{Ma}$, contains high carbonate values averaging $84.5 \% \pm 10 \%$. The first brief episode of lower carbonate values $(40 \%)$ occurs between 8.45 and $8.2 \mathrm{Ma}$, along with the oldest occurrence of diatomaceous sediments (30\%) (Ciesielski, Kristoffersen, et al., 1988). Interval 2, from 6.4 to $4.5 \mathrm{Ma}$, is characterized by relatively lower and more variable values averaging $61.7 \% \pm 17 \%$ (Fig. 2). The greatest variation and lowest mean values were measured between 5.46 and $4.96 \mathrm{Ma}$. At the base of the Thvera Subchron at $4.77 \mathrm{Ma}$, carbonate content abruptly increases and variance sharply diminishes (Fig. 2).

Bulk sediment- and carbonate-accumulation rates were highest during interval 1 between 8.71 and $7.35 \mathrm{Ma}$ (Fig. 2 and Table 4). Major decreases in accumulation rates occurred at 7.28 and at $6.37 \mathrm{Ma}$. The drop at $6.37 \mathrm{Ma}$ coincides with decreasing mean carbonate values. The increase in carbonate content at 4.77 Ma was not accompanied by an increase in the accumulation rate, because of reduced sedimentation rates during the early Pliocene (Fig. 2 and Table 4).

\section{Isotope Stratigraphy}

\section{Oxygen Isotopes}

Comparison of the oxygen isotopic and carbonate content records from between 5.4 and 4.8 Ma reveals that isotopic data are only available for those intervals characterized by high carbonate content, because in many highly siliceous samples foraminifers are either poorly preserved or absent. The average late Miocene benthic foraminifer $\delta^{18} \mathrm{O}$ value is $2.42 \% \pm 0.22 \%$, which is based on 148 analyses of Cibicidoides and Laticarinina. The $\delta^{18} \mathrm{O}$ average of Neoglo- 
Table 2. Stable isotopic results of benthic foraminifers from Cores 114-704B-24X through 114-704B-41X. No species-dependent correction factors are applied.

\begin{tabular}{|c|c|c|c|c|c|c|c|c|c|}
\hline $\begin{array}{l}\text { Depth } \\
\text { (mbsf) }\end{array}$ & $\begin{array}{c}\text { Age } \\
\text { (m.y.) }\end{array}$ & Species & $\begin{array}{c}\delta^{13} \mathrm{C} \\
(\% \circ \text { PDB })\end{array}$ & $\begin{array}{c}\delta^{18} \mathrm{O} \\
(\% \text { PDB })\end{array}$ & $\begin{array}{l}\text { Depth } \\
\text { (mbsf) }\end{array}$ & $\begin{array}{c}\text { Age } \\
\text { (m.y.) }\end{array}$ & Species & $\begin{array}{c}\delta^{13} \mathrm{C} \\
(\% \circ \text { PDB })\end{array}$ & $\begin{array}{c}\delta^{18} \mathrm{O} \\
(\% \circ \text { PDB })\end{array}$ \\
\hline 214.21 & 4.49 & Cibicidoides kullenbergi & 0.57 & 2.29 & 250.81 & 6.31 & Cibicidoides kullenbergi & 1.15 & 2.32 \\
\hline 214.51 & 4.51 & Cibicidoides kullenbergi & 0.52 & 2.21 & 251.11 & 6.32 & Laticarinina pauperata & 0.95 & 2.24 \\
\hline 215.71 & 4.59 & Cibicidoides kullenbergi & 0.44 & 2.26 & 251.41 & 6.34 & Cibicidoides kullenbergi & 1.56 & 2.17 \\
\hline 216.01 & 4.60 & Cibicidoides kullenbergi & 0.51 & 2.04 & 251.71 & 6.35 & Cibicidoides kullenbergi & 1.51 & 2.52 \\
\hline 217.21 & 4.66 & Cibicidoides kullenbergi & 0.37 & 2.36 & 252.20 & 6.37 & Cibicidoides kullenbergi & 1.60 & 2.35 \\
\hline 217.51 & 4.68 & Cibicidoides kullenbergi & 0.22 & 2.29 & 253.11 & 6.39 & Cibicidoides kullenbergi & 1.78 & 2.24 \\
\hline 219.01 & 4.75 & Cibicidoides kullenbergi & 0.54 & 2.40 & 253.70 & 6.41 & Cibicidoides kullenbergi & 1.57 & 2.50 \\
\hline 219.91 & 4.82 & Cibicidoides kullenbergi & 0.45 & 2.33 & 254.00 & 6.41 & Cibicidoides kullenbergi & 1.60 & 2.67 \\
\hline 220.81 & 4.92 & Cibicidoides kullenbergi & 0.95 & 2.29 & 255.20 & 6.44 & Cibicidoides kullenbergi & 1.48 & 2.47 \\
\hline 221.91 & 5.05 & Laticarinina pauperata & 0.15 & 2.12 & 256.70 & 6.48 & Cibicidoides kullenbergi & 1.35 & 2.59 \\
\hline 222.61 & 5.13 & Cibicidoides kullenbergi & 0.53 & 1.96 & 257.00 & 6.49 & Cibicidoides kullenbergi & 1.47 & 2.69 \\
\hline 223.10 & 5.18 & Cibicidoides kullenbergi & 0.35 & 2.14 & 258.20 & 6.57 & Cibicidoides kullenbergi & 1.16 & 2.65 \\
\hline 223.60 & 5.23 & Cibicidoides kullenbergi & 0.11 & 1.97 & 259.70 & 6.70 & Cibicidoides kullenbergi & 1.66 & 2.44 \\
\hline 223.71 & 5.25 & Cibicidoides kullenbergi & 0.05 & 2.02 & 260.61 & 6.72 & Cibicidoides kullenbergi & 1.62 & 2.47 \\
\hline 224.91 & 5.36 & Cibicidoides kullenbergi & 0.04 & 1.97 & 261.20 & 6.73 & Cibicidoides kullenbergi & 1.63 & 2.36 \\
\hline 225.10 & 5.36 & Oridorsalis sp. & -1.45 & 2.58 & 261.71 & 6.74 & Cibicidoides kullenbergi & 1.42 & 2.55 \\
\hline 225.51 & 5.38 & Cibicidoides kullenbergi & 1.02 & 2.28 & 263.51 & 6.76 & Cibicidoides kullenbergi & 1.27 & 2.43 \\
\hline \multirow[t]{2}{*}{225.79} & 5.38 & Uvigerina sp. & -0.08 & 2.53 & 264.71 & 6.80 & Cibicidoides kullenbergi & 1.43 & 2.66 \\
\hline & & Globocassidulina subglobosa & -0.04 & 2.83 & 266.21 & 7.00 & Cibicidoides kullenbergi & 1.20 & 2.25 \\
\hline 226.60 & 5.41 & Cibicidoides kullenbergi & 0.24 & 2.39 & 267.71 & 7.29 & Cibicidoides kullenbergi & 1.08 & 2.42 \\
\hline 226.71 & 5.41 & Cibicidoides kullenbergi & 0.60 & 2.55 & 269.21 & 7.32 & Cibicidoides kullenbergi & 1.57 & 2.38 \\
\hline 227.29 & 5.43 & Globocassidulina subglobosa & 0.33 & 3.05 & 270.71 & 7.36 & Cibicidoides kullenbergi & 1.71 & 2.52 \\
\hline \multirow[t]{2}{*}{227.61} & 5.44 & Globocassidulina subglobosa & 0.16 & 2.80 & 271.21 & 7.36 & Cibicidoides kullenbergi & 1.63 & 2.73 \\
\hline & & Uvigerina sp. & -0.11 & 3.37 & 274.21 & 7.40 & Cibicidoides kullenbergi & 1.43 & 2.47 \\
\hline 227.91 & 5.44 & Cibicidoides kullenbergi & -0.13 & 2.52 & 275.71 & 7.43 & Cibicidoides kullenbergi & 1.57 & 2.46 \\
\hline 228.10 & 5.45 & Globocassidulina subglobosa & -0.28 & 2.79 & 277.21 & 7.48 & Cibicidoides kullenbergi & 1.35 & 2.32 \\
\hline \multirow[t]{3}{*}{228.79} & 5.47 & Pullenia sp. & -0.58 & 2.92 & 280.21 & 7.58 & Cibicidoides kullenbergi & 1.17 & 2.78 \\
\hline & & Oridorsalis sp. & -0.60 & 2.56 & 280.71 & 7.59 & Cibicidoides kullenbergi & 1.36 & 2.73 \\
\hline & & Laticarinina pauperata & 0.26 & 1.82 & 283.11 & 7.67 & Cibicidoides kullenbergi & 1.39 & 2.73 \\
\hline 229.11 & 5.48 & Cibicidoides kullenbergi & 0.93 & 2.57 & 283.71 & 7.69 & Cibicidoides kullenbergi & 1.45 & 2.79 \\
\hline 229.41 & 5.49 & Cibicidoides kullenbergi & 0.66 & 2.54 & 286.71 & 7.79 & Cibicidoides kullenbergi & 1.34 & 2.59 \\
\hline 229.60 & 5.49 & Cibicidoides kullenbergi & 1.03 & 2.94 & 288.21 & 7.84 & Cibicidoides kullenbergi & 1.60 & 2.41 \\
\hline 229.71 & 5.49 & Cibicidoides kullenbergi & 0.84 & 2.35 & 289.66 & 7.89 & Cibicidoides kullenbergi & 1.48 & 2.69 \\
\hline 230.29 & 5.51 & Cibicidoides kullenbergi & 0.56 & 2.62 & 290.21 & 7.90 & Cibicidoides kullenbergi & 1.58 & 2.43 \\
\hline 230.61 & 5.52 & Cibicidoides kullenbergi & 0.93 & 2.57 & 291.70 & 7.92 & Cibicidoides kullenbergi & 1.45 & 2.61 \\
\hline 230.91 & 5.53 & Cibicidoides kullenbergi & 1.13 & 2.61 & 292.61 & 7.93 & Cibicidoides kullenbergi & 1.44 & 2.61 \\
\hline 231.10 & 5.53 & Cibicidoides kullenbergi & 1.21 & 2.83 & 293.21 & 7.93 & Cibicidoides kullenbergi & 1.36 & 2.49 \\
\hline 231.79 & 5.57 & Cibicidoides kullenbergi & 0.67 & 2.13 & 294.11 & 7.94 & Cibicidoides kullenbergi & 1.34 & 2.31 \\
\hline 232.41 & 5.60 & Cibicidoides kullenbergi & 0.36 & 2.50 & 294.71 & 7.95 & Cibicidoides kullenbergi & 1.26 & 2.48 \\
\hline 232.60 & 5.61 & Cibicidoides kullenbergi & 0.95 & 3.06 & 296.21 & 7.97 & Cibicidoides kullenbergi & 1.43 & 2.71 \\
\hline 232.71 & 5.62 & Globocassidulina subglobosa & 0.30 & 3.01 & 297.10 & 7.98 & Cibicidoides kullenbergi & 1.55 & 2.76 \\
\hline 233.21 & 5.64 & Cibicidoides kullenbergi & 0.73 & 2.54 & 297.71 & 7.98 & Cibicidoides kullenbergi & 1.16 & 2.39 \\
\hline 233.81 & 5.67 & Cibicidoides kullenbergi & 0.56 & 2.49 & 299.21 & 7.99 & Cibicidoides kullenbergi & 1.38 & 2.65 \\
\hline 234.11 & 5.68 & Cibicidoides kullenbergi & 0.98 & 2.82 & 299.71 & 8.00 & Cibicidoides kullenbergi & 1.63 & 2.61 \\
\hline 234.41 & 5.69 & Cibicidoides kullenbergi & 0.56 & 2.57 & 301.21 & 8.02 & Cibicidoides kullenbergi & 1.70 & 2.61 \\
\hline 234.71 & 5.70 & Cibicidoides kullenbergi & 1.22 & 2.71 & 302.11 & 8.03 & Cibicidoides kullenbergi & 1.53 & 2.46 \\
\hline 235.01 & 5.71 & Cibicidoides kullenbergi & 0.21 & 2.37 & 302.71 & 8.04 & Cibicidoides kullenbergi & 1.38 & 2.68 \\
\hline 235.51 & 5.72 & Cibicidoides kullenbergi & 0.71 & 2.45 & 304.21 & 8.05 & Cibicidoides kullenbergi & 1.11 & 2.40 \\
\hline 235.61 & 5.73 & Cibicidoides kullenbergi & 0.58 & 2.52 & 305.71 & 8.07 & Cibicidoides kullenbergi & 1.35 & 2.81 \\
\hline 235.91 & 5.73 & Cibicidoides kullenbergi & 0.59 & 2.64 & 308.11 & 8.10 & Cibicidoides kullenbergi & 1.33 & 2.60 \\
\hline 236.21 & 5.74 & Melonis barlearuum & -0.33 & 2.40 & 308.71 & 8.10 & Cibicidoides kullenbergi & 1.32 & 2.46 \\
\hline 237.01 & 5.76 & Cibicidoides kullenbergi & 0.85 & 2.25 & 309.21 & 8.11 & Cibicidoides kullenbergi & 1.47 & 2.20 \\
\hline 237.11 & 5.77 & Cibicidoides kullenbergi & 0.88 & 2.43 & 310.11 & 8.12 & Cibicidoides kullenbergi & 1.54 & 2.17 \\
\hline 237.41 & 5.78 & Cibicidoides kullenbergi & 0.43 & 2.57 & 313.71 & 8.16 & Cibicidoides kullenbergi & 1.72 & 2.43 \\
\hline 237.71 & 5.78 & Cibicidoides kullenbergi & 0.47 & 2.18 & 315.21 & 8.17 & Cibicidoides kullenbergi & 1.65 & 2.60 \\
\hline 238.01 & 5.79 & Globocassidulina subglobosa & 0.32 & 2.97 & 316.71 & 8.19 & Cibicidoides kullenbergi & 1.63 & 2.70 \\
\hline \multirow[t]{2}{*}{238.31} & 5.80 & Globocassidulina subglobosa & -0.17 & 1.85 & 318.21 & 8.21 & Cibicidoides kullenbergi & 1.45 & 2.49 \\
\hline & & Melonis sp. & -1.35 & 1.78 & 318.71 & 8.22 & Cibicidoides kullenbergi & 1.43 & 2.36 \\
\hline 238.51 & 5.81 & Cibicidoides kullenbergi & 0.11 & 2.18 & 320.21 & 8.27 & Cibicidoides kullenbergi & 1.35 & 2.30 \\
\hline 239.21 & 5.83 & Cibicidoides kullenbergi & 0.49 & 2.56 & 321.71 & 8.33 & Cibicidoides kullenbergi & 1.55 & 2.51 \\
\hline 240.10 & 5.85 & Cibicidoides kullenbergi & 1.21 & 2.83 & 323.21 & 8.38 & Cibicidoides kullenbergi & 1.30 & 2.45 \\
\hline 240.41 & 5.86 & Cibicidoides kullenbergi & 0.18 & 1.68 & 324.71 & 8.43 & Cibicidoides kullenbergi & 1.33 & 2.49 \\
\hline 243.91 & 6.00 & Cibicidoides kullenbergi & 0.68 & 2.29 & 326.21 & 8.47 & Cibicidoides kullenbergi & 1.31 & 2.60 \\
\hline 244.81 & 6.04 & Cibicidoides kullenbergi & 0.21 & 2.24 & 327.71 & 8.51 & Cibicidoides kullenbergi & 1.27 & 2.48 \\
\hline 245.11 & 6.05 & Cibicidoides kullenbergi & -0.22 & 2.44 & 328.21 & 8.52 & Cibicidoides kullenbergi & 1.24 & 2.26 \\
\hline 246.07 & 6.10 & Globocassidulina subglobosa & 0.04 & 2.96 & 328.21 & 8.52 & Cibicidoides kullenbergi & 1.17 & 2.41 \\
\hline 246.31 & 6.11 & Cibicidoides kullenbergi & 0.99 & 2.55 & 331.21 & 8.58 & Cibicidoides kullenbergi & 1.25 & 2.44 \\
\hline 246.60 & 6.12 & Cibicidoides kullenbergi & 1.06 & 2.42 & 337.71 & 8.70 & Cibicidoides kullenbergi & 1.32 & 2.26 \\
\hline 246.85 & 6.13 & Cibicidoides kullenbergi & 1.20 & 2.28 & 339.21 & 8.73 & Cibicidoides kullenbergi & 1.29 & 2.58 \\
\hline 247.21 & 6.15 & Cibicidoides kullenbergi & 0.89 & 1.82 & 340.71 & 8.76 & Cibicidoides kullenbergi & 1.38 & 2.17 \\
\hline 247.81 & 6.17 & Cibicidoides kullenbergi & 1.05 & 2.19 & 356.71 & 9.15 & Cibicidoides kullenbergi & 1.67 & 2.10 \\
\hline 248.11 & 6.19 & Globocassidulina subglobosa & 0.44 & 3.14 & 358.21 & 9.18 & Cibicidoides kullenbergi & 1.54 & 2.28 \\
\hline 248.41 & 6.20 & Globocassidulina subglobosa & 0.68 & 2.91 & 359.71 & 9.22 & Cibicidoides kullenbergi & 1.41 & 2.46 \\
\hline 249.31 & 6.24 & Laticarinina pauperata & 0.65 & 2.42 & 361.21 & 9.26 & Cibicidoides kullenbergi & 1.29 & 2.22 \\
\hline 249.91 & 6.27 & Cibicidoides kullenbergi & 1.10 & 2.40 & 362.71 & 9.29 & Cibicidoides kullenbergi & 1.26 & 2.05 \\
\hline \multirow[t]{2}{*}{250.21} & 6.28 & Cibicidoides kullenbergi & 1.25 & 2.32 & 364.21 & 9.33 & Cibicidoides kullenbergi & 1.42 & 2.11 \\
\hline & & Cibicidoides kullenbergi & 1.19 & 1.93 & 365.71 & 9.36 & Cibicidoides kullenbergi & 1.40 & 2.07 \\
\hline
\end{tabular}


Table 2 (continued).

\begin{tabular}{ccccc}
\hline $\begin{array}{c}\text { Depth } \\
\text { (mbsf) }\end{array}$ & $\begin{array}{c}\text { Age } \\
(\mathrm{m} . \mathrm{y} .)\end{array}$ & \multicolumn{1}{c}{ Species } & $\begin{array}{c}\delta^{13} \mathrm{C} \\
(\% \mathrm{PDB})\end{array}$ & $\begin{array}{c}\delta^{18} \mathrm{O} \\
(\% \text { PDB })\end{array}$ \\
\hline 366.21 & 9.38 & Cibicidoides kullenbergi & 1.44 & 2.03 \\
367.71 & 9.41 & Cibicidoides kullenbergi & 1.39 & 2.13 \\
369.21 & 9.45 & Cibicidoides kullenbergi & 1.10 & 2.37 \\
370.71 & 9.48 & Cibicidoides kullenbergi & 1.11 & 2.39 \\
372.21 & 9.52 & Cibicidoides kullenbergi & 1.22 & 2.47 \\
373.71 & 9.56 & Cibicidoides kullenbergi & 1.06 & 2.34 \\
375.21 & 9.59 & Cibicidoides kullenbergi & 1.43 & 2.44 \\
375.71 & 9.60 & Cibicidoides kullenbergi & 1.40 & 2.20 \\
377.21 & 9.64 & Cibicidoides kullenbergi & 1.36 & 2.27 \\
378.71 & 9.68 & Cibicidoides kullenbergi & 1.47 & 2.22 \\
380.21 & 9.71 & Cibicidoides kullenbergi & 1.43 & 2.42 \\
381.71 & 9.75 & Cibicidoides kullenbergi & 1.36 & 2.42 \\
384.71 & 9.82 & Cibicidoides kullenbergi & 1.34 & 2.25 \\
\hline
\end{tabular}

boquadrina pachyderma is $1.63 \%$, although with nearly twice the variance $( \pm 0.4 \%$ oo $)$ of the benthic record.

Between 8.8 and $6.4 \mathrm{Ma}, \delta^{18} \mathrm{O}$ values show little variance. A first gradual increase of the benthic $\delta^{18} \mathrm{O}$ above the average can be noted within this time interval between 8.8 and $8 \mathrm{Ma}$ (Fig. 3), with a final step of $0.64 \%$ oo toward more positive values at about 8.1 Ma.

At $6.3 \mathrm{Ma}$, benthic and planktonic $\delta^{18} \mathrm{O}$ values begin to decrease, coinciding with a drop in carbonate content of the sediment (Fig. 3). Decreasing $\delta^{18} \mathrm{O}$ values continue to 5.8 $\mathrm{Ma}$, with several brief minima in both benthic and planktonic records. The successive decreases in benthic $\delta^{18} \mathrm{O}$ values are followed by an increase between 5.8 and $5.4 \mathrm{Ma}$. Based on the few values between 5.4 and $4.8 \mathrm{Ma}$, it appears that mean values are lower in this interval than the previous one, although this may simply reflect decreased resolution and sampling of the high-carbonate events. Lastly, the interval between 4.76 and $4.5 \mathrm{Ma}$ has planktonic isotopic ratios above $2 \%$ between 4.7 and $4.63 \mathrm{Ma}$, with the most positive value $(2.38 \%$ oo $)$ of the entire record at $4.66 \mathrm{Ma}$.

\section{Carbon Isotopes}

Between 9.8 and $6 \mathrm{Ma}$ benthic and planktonic carbon isotopic records are covariant (Fig. 3). High-amplitude variations are common in both signals, whereas after $8.2 \mathrm{Ma}$, at $318.3 \mathrm{~m}$ below seafloor (mbsf), the amplitude in the planktonic record increases. In the upper part of the $\delta^{13} \mathrm{C}$ record (6 to $4.4 \mathrm{Ma}$ ) planktonic and benthic variations are out of phase.

The late Miocene (Chron C3AR) carbon shift occurs between $6.4 \mathrm{Ma}(253.11 \mathrm{mbsf})$ and $6.0 \mathrm{Ma}(243.91 \mathrm{mbsf})$ in both planktonic and benthic signals (Fig. 4). The difference between the averages of both curves prior to and after the shift is $0.85 \%$. The total range between the most positive and negative values is $2 \%$ in the benthic record and $1.5 \%$ in the planktonic record. Benthic isotopic values reach a temporary plateau between $6.4 \mathrm{Ma}(253.11 \mathrm{mbsf})$ and $6.3 \mathrm{Ma}$ (250.81 mbsf) (Fig. 4).

\section{DISCUSSION}

\section{Carbonate Record}

The carbonate content of the pelagic sediments is a complex function of the production rate of carbonate microfossils, dilution by noncarbonate sedimentary components, and dissolution of carbonate in the water column or on the seafloor. It is typically difficult to decipher which of these causes is the dominant control on carbonate variation at any given time. Utilizing information on the carbonate, opal, and nonbiogenic components of the sediment, as well as diatom assemblage
Table 3. Isotope adjustment factors to correct benthic species to Cibicidoides kullenbergi.

\begin{tabular}{lcc}
\hline \multicolumn{1}{c}{ Species $^{\mathrm{a}}$} & ${ }^{18} \mathrm{O}$ & ${ }^{13} \mathrm{C}$ \\
\hline Uvigerina sp. & -0.5 & 0.9 \\
Melonis sp. & -0.2 & 0.8 \\
Melonis barlearuum & -0.1 & 1.0 \\
Oridorsalis sp. & -0.5 & 1.0 \\
Globocassidulina subglobosa & -0.6 & 0.5 \\
Laticarinina pauperata & 0.14 & 0.0 \\
Pullenia sp. & -0.5 & 0.3 \\
\hline a All after Shackleton et al. (1984), except Laticarinina \\
\multicolumn{2}{c}{ pauperata after Woodruff et al. (1980). }
\end{tabular}

data, we suggest major productivity and dissolution events during the late Miocene.

The first low values in the Neogene carbonate record at Hole 704B occur at 8.45-8.2 Ma (Fig. 2). This minimum is associated with an increase in opal and nonbiogenic components of the sediment and could have been caused either by dissolution (correlation to dissolution event 10e in the Pacific; Froelich et al., this volume) or by dilution of the sediment by siliceous fossils caused by a first approach of the subantarctic biosiliceous productivity zone near Site 704 .

The dominant feature of the late Miocene carbonate record is the low-carbonate interval between 6.3 and $4.8 \mathrm{Ma}$ (Fig. 4). Overall, this is an interval of increased opal content (Froelich et al., this volume), greater frequency of upwelling diatom indicators (Fenner, this volume), increased dissolution as evidenced by foraminifers (Brunner, this volume), and increased accumulation of nonbiogenic sedimentary components (Froelich et al., this volume).

The initial decrease in carbonate content at 6.3-6.4 Ma is coincident with the Chron C3AR carbon shift (Fig. 4). Diatom assemblages indicate relatively low surface water productivity between 6.4 and $6.0 \mathrm{Ma}$ (Fenner, this volume), suggesting that this initial period of low carbonate was an artifact of dissolution rather than decreased carbonate productivity or dilution by biogenic silica. This conclusion is supported by a planktonic foraminifer visual preservation index that shows generally good preservation prior to $6.4 \mathrm{Ma}$ and predominantly poor preservation between 6.4 and 4.8 Ma (Brunner, this volume).

Extreme changes in diatom assemblages at $\sim 6.0 \mathrm{Ma}$ indicate that intense upwelling conditions moved over the site and persisted until 5.4 Ma (Fenner, this volume). Accompanying this upwelling episode was an increase in opal content of the sediments (Froelich, et al., this volume). This interval, marked by major upwelling, began during the latter phase of the second part of the carbon shift and apparently marks the northward migration of the Subantarctic Front to within close proximity of the site. This condition was followed by a $1.15 \%$ increase in benthic $\delta^{18} \mathrm{O}$ values at $5.86 \mathrm{Ma}$, suggesting a glacial event.

The earliest Gilbert Chron, between 5.35 and 4.77 Ma, was marked by the lowest mean carbonate values $(47.5 \%)$ and the greatest accumulation rates of nonbiogenic material (Froelich et al., this volume). During this interval, sedimentation rates were low $(8.9 \mathrm{~m} / \mathrm{m}$.y.) and dominated by abiogenic components (i.e., clay, quartz, feldspar, and abundant pyrite). Planktonic foraminifers are also poorly preserved in the sediment throughout the early Gilbert Chron and are entirely absent between 5.05 and $5.10 \mathrm{Ma}$ (Brunner, this volume), where carbonate content is only $4.75 \%(222.31 \mathrm{mbsf})$. Although no isotopic measurements were possible from this dissolution interval, it probably correlates with a major glacial peak between 5.1 and $5.0 \mathrm{Ma}$ as inferred by data from other sites 
Table 4. Sedimentation rate, mean dry-bulk density and carbonate content, bulk-sediment and carbonate mass-accumulation rates, and average sampling densities for the upper Miocene in Hole 704B.

\begin{tabular}{|c|c|c|c|c|c|c|c|c|}
\hline \multirow[b]{2}{*}{$\begin{array}{l}\text { Depth } \\
\text { (mbsf) }\end{array}$} & \multirow[b]{2}{*}{$\begin{array}{c}\text { Age } \\
\text { (m.y.) }\end{array}$} & \multirow[b]{2}{*}{$\begin{array}{l}\text { Sedimentation } \\
\text { rate }(\mathrm{m} / \mathrm{m} . \mathrm{y} .)\end{array}$} & \multirow{2}{*}{$\begin{array}{c}\text { Mean } \\
\text { dry-bulk } \\
\text { density } \\
\left(\mathrm{g} / \mathrm{cm}^{3}\right)\end{array}$} & \multirow{2}{*}{$\begin{array}{c}\text { Mean } \\
\text { carbonate } \\
\text { content }(\%)\end{array}$} & \multirow[b]{2}{*}{$\begin{array}{l}\text { Standard } \\
\text { deviation }\end{array}$} & \multicolumn{2}{|c|}{$\begin{array}{l}\text { Mass-accumulation } \\
\text { rate }\left(\mathrm{g} / \mathrm{cm}^{2} / 10^{3}\right)\end{array}$} & \multirow{2}{*}{$\begin{array}{l}\text { Average } \\
\text { sampling } \\
\text { density } \\
(1000 \mathrm{yr})\end{array}$} \\
\hline & & & & & & $\begin{array}{c}\text { Bulk } \\
\text { sediment }\end{array}$ & Carbonate & \\
\hline 212.00 & 4.4 & 7.41 & 1.01 & 77.7 & & 0.75 & 0.58 & \\
\hline $\begin{array}{l}214.00 \\
215.30\end{array}$ & $\begin{array}{l}4.47 \\
4.57\end{array}$ & 13.0 & 0.95 & 76.2 & 4.2 & 1.24 & 0.94 & 20 \\
\hline 219.45 & 4.77 & 20.8 & 0.87 & 72.0 & 11.85 & 1.81 & 1.3 & 12 \\
\hline 224.60 & 5.35 & 8.9 & 0.77 & 47.5 & 20.7 & 0.69 & 0.33 & 29 \\
\hline 231.00 & 5.53 & 35.6 & 0.74 & 58.6 & 18.7 & 2.63 & 1.54 & 7.5 \\
\hline 233.86 & 5.68 & 19.1 & 0.9 & 62.6 & 7.75 & 1.72 & 1.08 & 15.0 \\
\hline 241.5 & 5.89 & 36.4 & 0.83 & 55.8 & 13.1 & 3.0 & 1.68 & 10.5 \\
\hline 252.2 & 6.37 & 22.3 & 0.99 & 69.7 & 16.7 & 2.2 & 1.53 & 17.2 \\
\hline 257.5 & 6.5 & 40.8 & 1.2 & 86.3 & 6.36 & 4.89 & 4.22 & 6.5 \\
\hline 259.5 & 6.7 & 10.0 & 1.26 & 86.6 & 3.74 & 1.26 & 1.09 & 28.5 \\
\hline 264.5 & 6.78 & 62.5 & 1.18 & 84.6 & 7.00 & 7.35 & 6.22 & 4.5 \\
\hline 265.5 & 6.85 & 14.3 & 1.24 & 83.6 & 1.63 & 1.77 & 1.48 & 23.4 \\
\hline 267.5 & 7.28 & 4.7 & 1.2 & 86.0 & 3.24 & 0.56 & 0.49 & 61.5 \\
\hline 270.2 & 7.35 & 38.6 & 1.28 & 83.8 & 8.8 & 4.94 & 4.14 & 10.0 \\
\hline 275.2 & 7.41 & 83.3 & 1.17 & 82.2 & 8.62 & 9.77 & 8.03 & 3.6 \\
\hline 290.0 & 7.9 & 30.2 & 1.3 & 86.7 & 4.3 & 3.91 & 3.39 & 15.3 \\
\hline 318.5 & 8.21 & 91.9 & 1.27 & 86.6 & 7.75 & 11.7 & 10.1 & 5.54 \\
\hline 324.1 & 8.41 & $\begin{array}{l}28 \\
32.8\end{array}$ & $\begin{array}{l}1.08 \\
1.08\end{array}$ & $\begin{array}{l}59.0 \\
71.3\end{array}$ & $\begin{array}{l}14.0 \\
14.0\end{array}$ & 3.28 & 2.14 & 17.0 \\
\hline 327.05 & 8.5 & & & & & & & \\
\hline 338.55 & 8.71 & 54.8 & 1.29 & 87.7 & 6.0 & 7.07 & 6.2 & 21.0 \\
\hline 409.64 & 10.4 & 41.6 & 1.3 & 84.9 & 5.51 & 5.41 & 4.6 & 30.2 \\
\hline
\end{tabular}

(McKenzie and Oberhänsli, 1985; Hodell and Kennett, 1986; Keigwin et al., 1987). The severe dissolution in the early Gilbert Chron ended at $4.8 \mathrm{Ma}$, when the carbonate content increased to $75.3 \% \pm 5.1 \%$ and planktonic foraminifers became more diverse and better preserved (Brunner, this volume). All of these indicators suggest that the earliest Gilbert Chron was marked by a severe dissolution event at Site 704.

Site 704 , positioned at $2500 \mathrm{~m}$ water depth, is relatively shallow with respect to the lysocline and CCD. In fact, Hsü and Wright (1985) suggested that the depth of the lysocline in the southwest Atlantic Ocean was always deeper than $2.5 \mathrm{~km}$ between 11 and $4 \mathrm{Ma}$. The decrease in carbonate content in Site 704 at $2500 \mathrm{~m}$ suggests a lysocline shallower than $2500 \mathrm{~m}$ during intervals of the latest Miocene between 6.4 and $4.8 \mathrm{Ma}$. Such intense dissolution at a relatively shallow depth $(\sim 2500$ $\mathrm{m}$ ) has also been noted on the Walvis Ridge between 5.3 and 4.5 Ma (M. L. Prentice, unpubl. data).

The late Miocene represented a time of fundamental change in the carbonate saturation of the oceans. In fact, low carbonate values are an almost ubiquitous feature of the deep-sea carbonate records during the late Miocene (Ryan et al., 1974; Thunell, 1981; Dunn et al., 1981; Vincent et al., 1980; Pisias and Prell, 1985; Jansen et al., in press; among others). This global decrease in carbonate content represents a marked shoaling of the lysocline and CCD, partially caused by the Messinian salinity crisis of the Mediterranean Sea (see "Correlation between the Southern Ocean and the Mediterranean Sea").

Between 4.8 and $4.5 \mathrm{Ma}$ in the early Pliocene, carbonate saturation of bottom waters increased, as suggested by high, invariant carbonate values (see also Froelich et al., this volume; Hodell and Ciesielski, this volume), assuming that this is related to preservation effects alone.

\section{Stable Isotopic Stratigraphy}

Early Late to Middle Late Miocene (9.8 to 6.4 Ma)

Between 8.8 and $8 \mathrm{Ma}$, benthic foraminifers in Hole 704B record a mean increase of roughly $0.4 \% 0$ in $\delta^{18} \mathrm{O}$ values. A similar $\delta^{18} \mathrm{O}$ increase after the middle Miocene ice buildup was also reported from DSDP Site 289 , located in the equatorial Pacific, between 9 and $8.5 \mathrm{Ma}$. Kennett (1986) also documented an increase in $\delta^{18} \mathrm{O}$ ratios in the southwest Pacific over the middle/late Miocene boundary. He dated this oxygen isotopic event at $11 \mathrm{Ma}$ using a correlation of anomaly 5 to Chron C4AN, but we suggest that this event is correlative to the increase found in Hole 704B dated between 8.8 and $8 \mathrm{Ma}$ using an anomaly 5-Chron $\mathrm{C} 5 \mathrm{~N}$ correlation. Grounded ice 


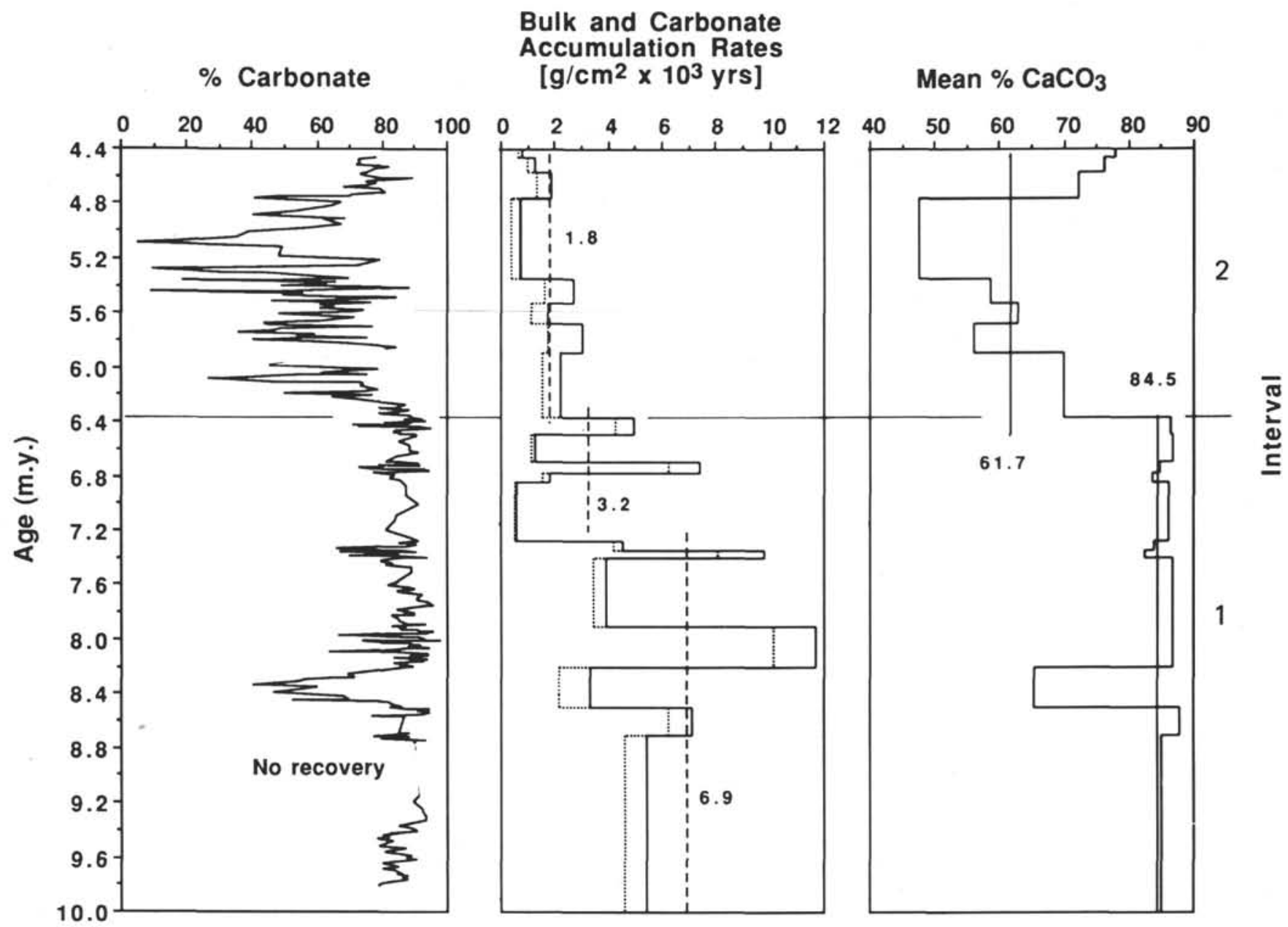

Figure 2. Percent carbonate, bulk sediment- (solid line) and carbonate- (dotted line) accumulation rates, and mean percent carbonate in the upper Miocene of Hole 704B. Intervals 1 and 2 are marked by the horizontal line.

shelves in West Antarctica are inferred to have been absent prior to $8.7 \mathrm{Ma}$ (Ciesielski and Weaver, 1983; Barker, Kennett, et al., 1988). The first ice rafting at Site 513 in the southwest subantarctic South Atlantic was noted at $8.7 \mathrm{Ma}$ (Ciesielski and Weaver, 1983; Ludwig, Krasheninnikov, et al., 1983). Microfossil assemblages before $9 \mathrm{Ma}$ in Hole 704B are consistent with a position close to the Subtropical Convergence (Fig. 1; Ciesielski, Kristoffersen, et al., 1988). At 9 Ma, the abundance of the globorotalids also decreases, which suggests cooling of the subantarctic region (Ciesielski, Kristoffersen, et al., 1988, p. 645, fig. 13).

At other sites located in the subantarctic, the late Miocene is commonly represented by erosion or nondeposition that has been ascribed to an intensification of the Antarctic Circumpolar Current (ACC). For example, Site 699 in the West Georgia Basin is bathed by CPDW, and a hiatus spans the interval from approximately 8.5 to $4.5 \mathrm{Ma}$. A highly condensed late Miocene section occurs at Site 513 between 8.5 and $6.5 \mathrm{Ma}$ (Ludwig, Krasheninnikov, et al., 1983; Wise et al., 1985). The increase in $\delta^{18} \mathrm{O}$ between 8.8 and 8 Ma may have coincided with cooling and intensification of the ACC or a northward expansion of the ACC. Our reported temperature change is in the range of changes within the same bottom water mass $\left(2^{\circ} \mathrm{C}\right)$ during glaciations (Shackleton, 1982; Duplessy et al., 1985; Chappell and Shackleton, 1986). On the other hand, a northward migration of the water-mass boundary between NADW and ACC can also cause a temperature drop by nearly $2^{\circ} \mathrm{C}$. The modern temperature difference between the NADW and the ACC is measured to be $1.88^{\circ} \mathrm{C}$ (Oppo and Fairbanks, 1987).

\section{Latest Miocene to Earliest Pliocene ( 6.4 to $4.5 \mathrm{Ma}$ )}

\section{Oxygen Isotopes and Carbonate Fluctuations}

A strong decrease in both benthic and planktonic oxygen isotopic signals takes place at $6.15 \mathrm{Ma}$ (Fig. 4). The unusually low planktonic $\delta^{18} \mathrm{O}$ value at $6.15 \mathrm{Ma}$ suggests extremely warm surface water conditions in the subantarctic at this time. Correlation of diatom datum levels and magnetostratigraphy between Sites 704 and 701 suggests that the laminated, organic-rich Neobrunia ooze was deposited near this time. Subtropical-tropical diatoms and silicoflagellates within the Neobrunia ooze indicate warm sea surface temperatures. The Neobrunia ooze was rapidly deposited during a very brief period of time (some $10^{4} \mathrm{yr}$ ). Perhaps the large amplitude of the planktonic $\delta^{18} \mathrm{O}$ signal in Site 704 at $6.15 \mathrm{Ma}$ is not surprising considering the location of this site relative to the PFZ. Between $41^{\circ}$ and $60^{\circ} \mathrm{S}$ in the South Atlantic the gradient in $\delta^{18} \mathrm{O}$ of Neogloboquadrina pachyderma from core tops increases by $3 \%$ (Charles and Fairbanks, in press). Any translations of these frontal boundaries are sure to produce marked fluctuations in planktonic $\delta^{18} \mathrm{O}$ records. 
Table 5. Paleomagnetic and selected biostratigraphic datum levels in Hole 704B.

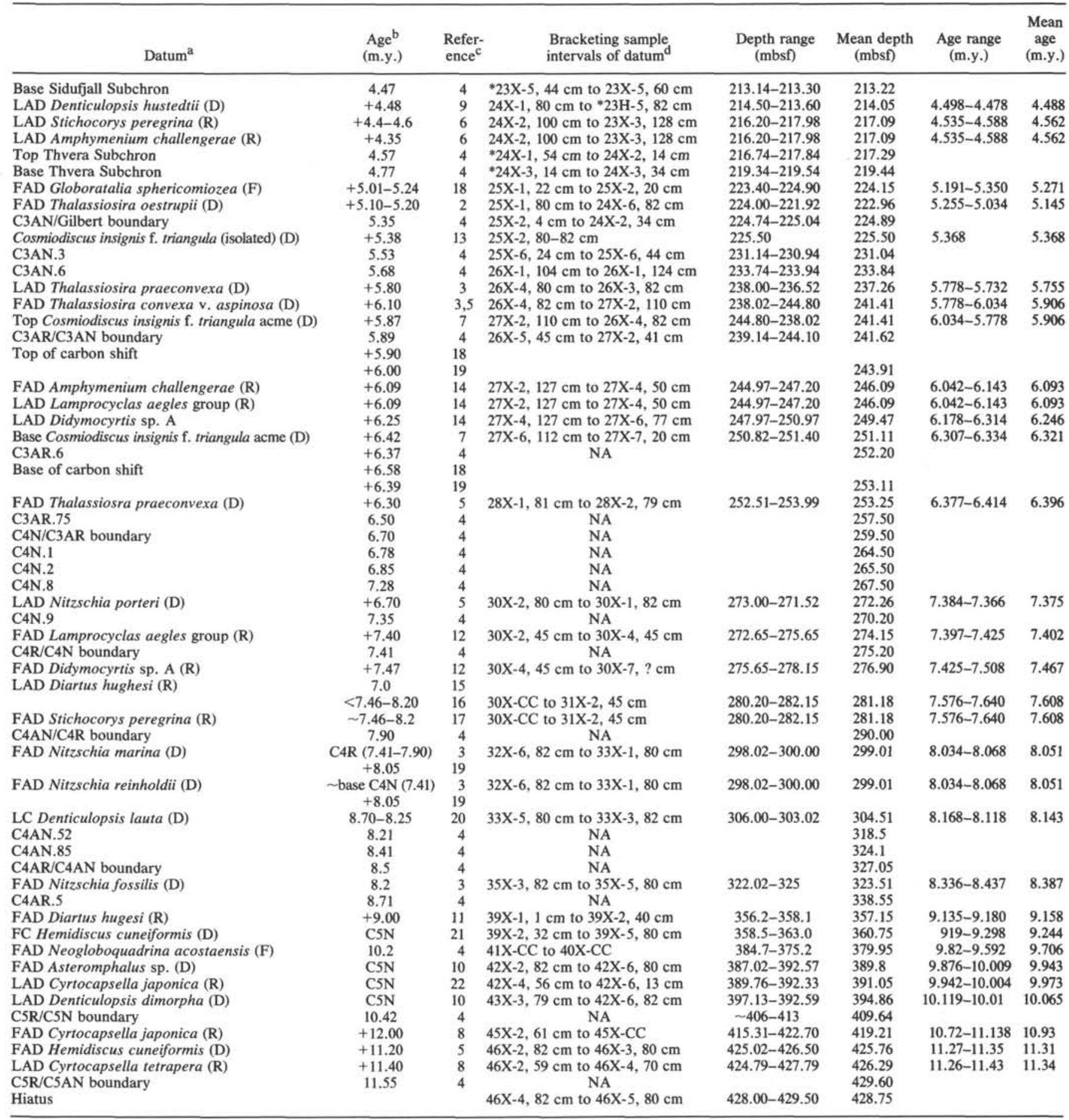

${ }^{\mathrm{a}} \mathrm{FAD}=$ first-appearance datum $; \mathrm{LAD}=$ last-appearance datum $\mathrm{LAAD}=$ last abundant appearance datum; $\mathrm{LC}=$ last consistent appearance $\mathrm{FC}=$ first consistent appearance; $\mathrm{D}=$ diatom; $\mathrm{F}=$ foraminifer; $\mathrm{R}=$ radiolarian.

$\mathrm{b}+=$ direct correlation to paleomagnetic stratigraphy.

c 1 = Dumont et al. (1986). 2 = Baldauf (1985). 3 = Barron (1985). Ages of FADs of $N$. reinholdii and $N$. marina are based upon the depth of these datums in Hole 575 and the paleomagnetics by Weinreich and Theyer's (Barron et al., 1985b) assignment of paleomagnetic chrons. These data suggest an older age for these datums than previously noted from lower latitudes and are in agreement with ages provided here. Occurrences of both species below C3AR are sporadic and increase significantly at this level close to their noted FAD elsewhere, $4=$ Berggren et al. (1985). $5=$ Burckle (1978). $6=$ Weaver $(1983) .7=$ Barron et al. $(1985) .8=$ Johnson and Wick (1982), 9 = Ciesielski (1983), $10=$ By inference is placed within Chron C5N, found above the first $N$. acostaensis (10.2 Ma) at Site 329 and is not present above a radiometrically age-dated volcanic ash horizon $(8.7 \mathrm{Ma}$ ) at Site $513.11=$ Theyer et al. (1978). $12=$ These datums are corrected from Weaver (1983). The FADs of Lamprocyclus aegles group and Didymocyrtis sp. A occur almost concurrently at Sites 513 and 704. These datums are above the LADs of D. hughesi and Denticulopsis lauta at both sites and well below the carbon shift of Hole 704B, supporting the paleomagnetic polarity identifications and ages assigned here. $13=$ P. F. Ciesielski (unpubl. data). $14=$ These datums are corrected from Weaver (1983). The LADs of Didymocyrtis sp. A and the Lamprocyclus aegles group and the FAD of Amphymenium challengerae occur nearly simultaneous at Sites 513 (Weaver, 1983) and 704 (Ling, this volume). These datums also occur within the (Explanation continued on facing page) 


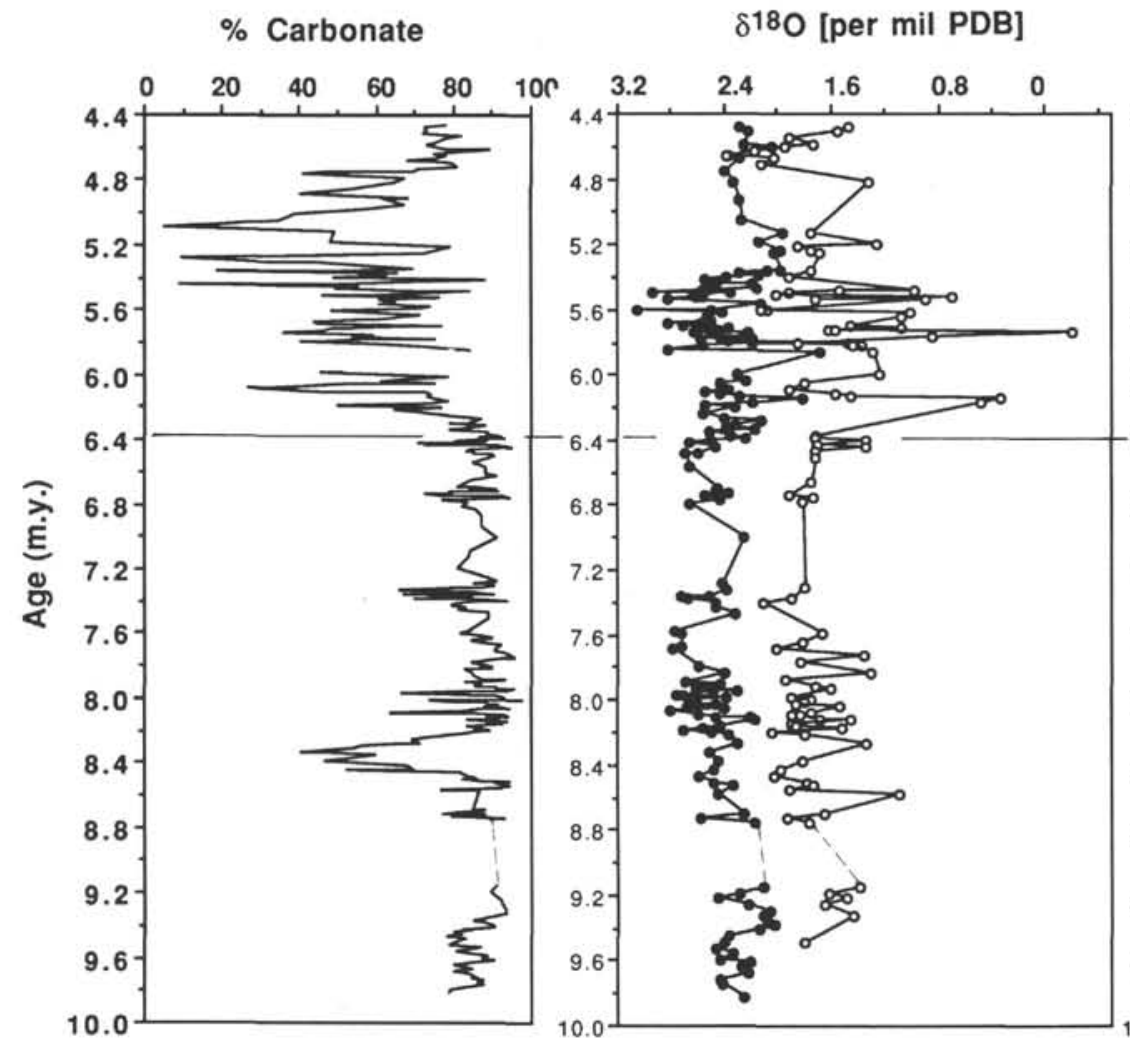

$\delta 180$ [per mil PDB]

$\delta^{13} \mathrm{C}$ [per mil PDB]

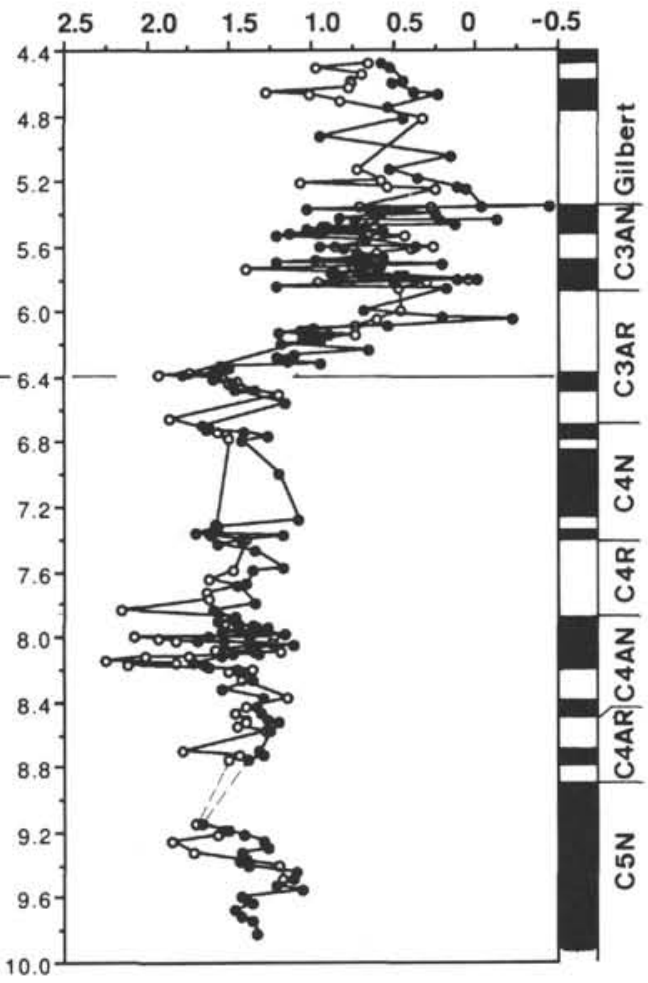

Figure 3. Percent carbonate, $\delta^{18} \mathrm{O}$, and $\delta^{13} \mathrm{C}$ in the upper Miocene of Hole 704B. Open symbols are the left-coiled planktonic foraminifer $N$. pachyderma; solid symbols are benthic foraminifers, mainly $C$. kullenbergi. Magnetostratigraphy is from Hailwood and Clement, this volume. The horizontal line divides intervals 1 and 2 .

An alternative interpretation is that the anomalously low planktonic $\delta^{18} \mathrm{O}$ events represent salinity effects caused by deglaciation meltwater. McKenzie and Oberhänsli (1985) reported marked variation in the $\delta^{18} \mathrm{O}$ of Orbulina universa at the South Atlantic Site 519. These anomalously low $\delta^{18} \mathrm{O}$ values were interpreted as representing brief deglaciation events that introduced large volumes of isotopically light meltwater into the Benguela Current. Labeyrie et al. (1986) also found anomalously low planktonic $\delta^{18} \mathrm{O}$ values in the late Quaternary, between 35,000 and 17,000 yr, which they suggested resulted from a meltwater lid that covered the Southern Ocean PFZ. Values of $\delta^{18} \mathrm{O}$ increase again at $6.1 \mathrm{Ma}$, suggesting conditions comparable to those that existed prior to the warming event at $6.15 \mathrm{Ma}$. In the same time interval, the first extreme carbonate minimum $(26 \%)$ occurs at $6.1 \mathrm{Ma}$; the samples are dominated by "diatom-cotton" between 6.1 and
5.4 Ma. Diatom assemblages in this interval suggest upwelling and high-productivity conditions.

At $5.85 \mathrm{Ma}$, benthic $\delta^{18} \mathrm{O}$ values increase, marking the beginning of a prolonged glacial interval that lasted until $\sim 5.4$ Ma. Superimposed on this are two additional $\delta^{18} \mathrm{O}$ increases recorded in both planktonic and benthic foraminifers at 5.6 and 5.5 Ma. Similar increases in $\delta^{18} \mathrm{O}$ values during this interval have been reported from the southwest Pacific (Hodell and Kennett, 1986), South Atlantic (McKenzie and Oberhänsli, 1985), and North Atlantic (Keigwin et al., 1987). Between the glacial peaks at 5.6 and $5.5 \mathrm{Ma}$ is a brief interglacial interval at $5.54 \mathrm{Ma}$, marked by a decrease in planktonic and benthic $\delta^{18} \mathrm{O}$ and the common occurrence of the warm-water silicoflagellate Dictyocha.

An inadequate number of $\delta^{18} \mathrm{O}$ values is available in the interval between 5.05 and $4.75 \mathrm{Ma}$; however, based on the

acme of Cosmiodiscus insignus v. triangula at both sites (Cisielski, 1983; Fenner, this volume) and within the carbon shift (this paper). $15=$ Barron et al. (1985b). $16=$ The last $D$. hughesi in the subantarctic must be slightly younger than the first occurrence of Discoaster quinqueramus ( 8.2 Ma, Berggren et al., $1985 ; 7.46$ Ma, Backman et al., in press). The calculated age of this datum in Hole 704B is $7.6 \mathrm{Ma}$, based on the paleomagnetic interpretation herein. $17=$ The first occurrence of $S$. peregrina in equatorial Pacific cores has been tied to above the normal of C3AR $(6.2-6.3 \mathrm{Ma}$, Theyer and Hammond, 1984) to near the C4N/C3AR boundary (Burckle, 1972). This datum appears to be considerably older in the subantarctic. In Hole 704B it is coincident (or nearly so) with the LAD D. hughesi and at Site 594 it occurs slightly below the last LAD D. hughesi and is bracketed by the LAD Discoaster hamatus (8.67 Ma, Backman et al., in press; 8.85 Ma, Berggren et al., 1985) and the FAD Discoaster quinqueramus (7.46 Ma, Backman et al., in press; 8.2 Ma, Berggren et al., 1985). Being only a few meters below the D. quinqueramus datum at Site 594 the age estimates for this datum are employed here with the interpolated age of the $S$. peregrina falling precisely between these estimates. $18=$ Hodell and Kennett (1986), $19=$ Age based solely upon paleomagnetic polarity interpretation of Hole 704B. 20 = The last consistent $D$. Iauta has been shown to be younger than the radiometrically dated ash layer at Site $513(8.7 \mathrm{Ma})$ and older than the FAD Discoaster quinqueramus at Site 594 . The last consistent occurrence of the species, therefore, is likely C4AN and close to the estimate of $\sim 8.25$ given in Barron (1986b). $21=$ Although the FAD of $H$. cuneiformis first occurs in Chron C5R it is very rare until Chron C5N. Ciesielski (1983) notes it below the 8.7 Ma ash of Site 513, and its first consistent occurrence is above the FAD Neogloboquadrina acostaensis datum (10.2 Ma) at Sites 329 and 704, placing this event within Chron C5N. $22=C y r t o c a p s e l l a$ japonica is sparse in its upper range, however, its LAD is older than the $8.7 \mathrm{Ma}$ ash at Site 513 and just below the FAD N. acostaensis, probably placing it in basal C5N,

$\mathrm{d}_{*}^{*}=$ sample from Hole $704 \mathrm{~A} ; \mathrm{NA}=$ interval not available. 

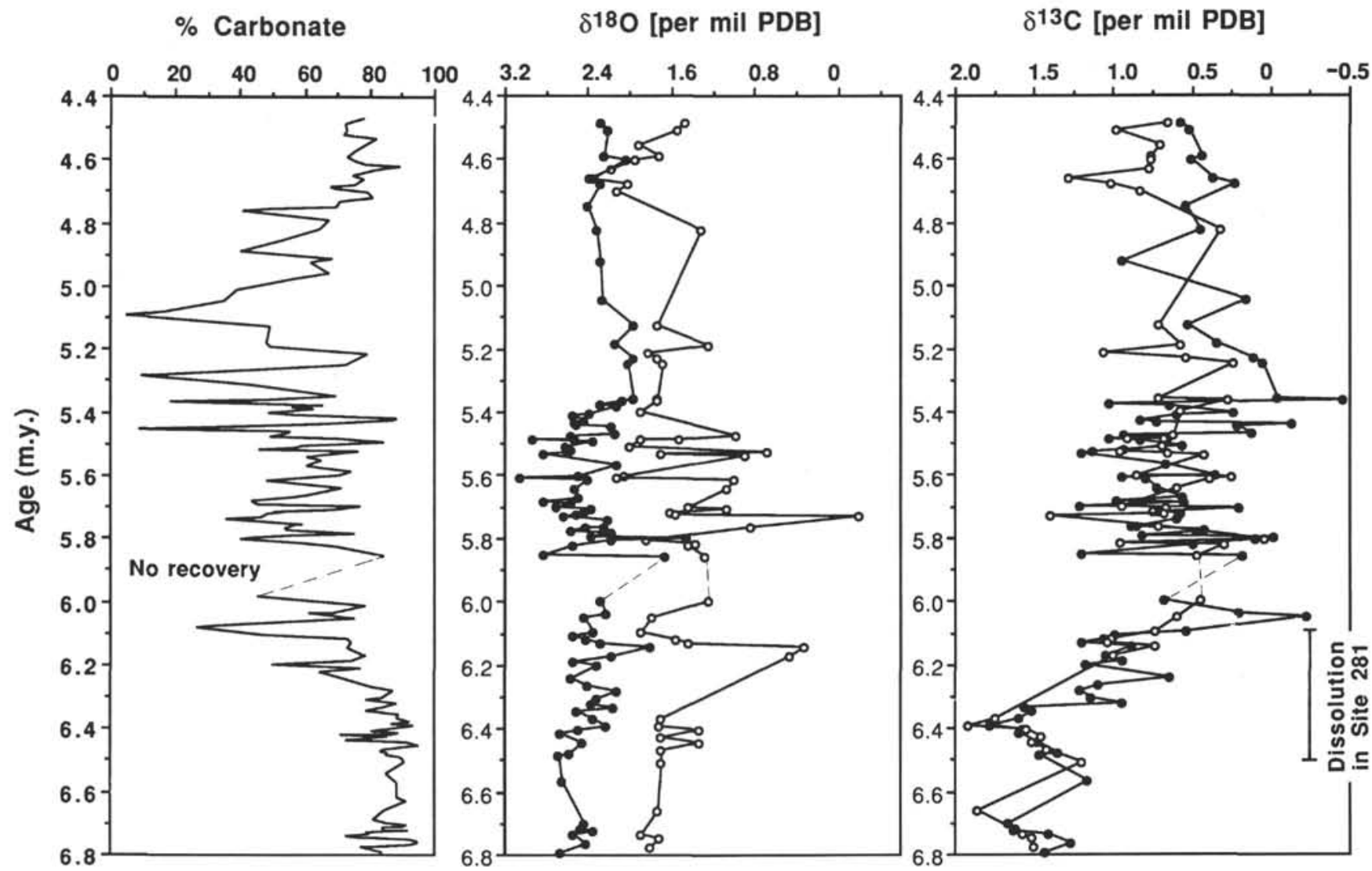

Figure 4. The pre- to post-carbon shift record of the upper Miocene-lowermost Pliocene of Hole 704B illustrating variability in percent carbonate, and the stable isotope values of $\delta^{18} \mathrm{O}$ and $\delta^{13} \mathrm{C}$ measured for planktonic (open symbols) and benthic (solid symbols) foraminifers. Note the pronounced carbon isotopic decrease; the more measured, detailed benthic $\delta^{13} \mathrm{C}$ record reveals an initial shift between 6.4 and $6.3 \mathrm{Ma}$, a plateau or stabilization of values between 6.3 and $6.12 \mathrm{Ma}$, and a further shift in values between 6.12 and $6.0 \mathrm{Ma}$.

diatom and silicoflagellate assemblages surface waters appear to have been very warm with the Subantarctic Front located to the South. The diatom assemblages are diverse, containing many lower latitude forms, including Actinocyclus ellipticus, A. ehrenbergii var. tenella, A. cubitus, T. hyalinopsis, and Thalassiosira convexa var. aspinosa, as well as species of the silicoflagellate genus Dictyocha. The high-frequency fluctuations in Hole 704B during the late Miocene suggest climatic instability that may have included effects of temperature, salinity, and pulses of ice sheet growth and decay (Keigwin et al., 1987; Hodell and Kennett, 1986). One possible source of this instability may have been the West Antarctic Ice Sheet, which may have grounded episodically during this period. Because the West Antarctic Ice Sheet is largely marine based, it is inherently less stable than the continentally based East Antarctic Ice Sheet and is therefore sensitive to relatively small changes in the sea surface temperature of the Southern Ocean (Mercer, 1978). Thus, during the late Miocene, fluctuating temperatures in the Southern Ocean resulted in a period of instability during the initial formation of the West Antarctic Ice Sheet, causing frequent accretion and ablation of the ice sheet.

Deglaciation events of West Antarctica could have produced meltwater lids over the Southern Ocean and may have decreased or halted the production of Antarctic Bottom Water (AABW) for brief intervals. One consequence of a temporary $A A B W$ shutoff would have been a decrease in the ventilation rate of the deep basins of the South Atlantic, the occurrence of which is evidenced by the laminated, organic-carbon-rich sediments, such as the Neobrunia ooze in Hole 701, which indicates suboxic to anoxic bottom water. Similar laminated, organic-carbon-rich diatomites have also been described from DSDP Site 520 , located $26^{\circ}$ to the north of Site 701 (Gombos, 1984). The synchronous deposition of laminated diatomites at both Sites 701 and 520 suggests that this suboxic event may have been a basin-wide phenomenon throughout the South Atlantic.

The end of the early Gilbert (5.05-4.75 Ma) warm conditions could be closely age equivalent to the cessation of turbidite deposition at Site 694 (northern Weddell Sea), which was tentatively dated at $4.8 \mathrm{Ma}$ (Barker, Kennett, et al., 1988). This event is interpreted as representing a transition in the configuration of the West Antarctic Ice Sheet from unstable to stable. The cold surface water peak of Site 704 at $4.66 \mathrm{Ma}$ is caused by a brief cooling without effect on sea level during a time of increased carbonate-accumulation rate. Limited data in the benthic $\delta^{18} \mathrm{O}$ show no sign of a large ice volume increase. The surface to deep oxygen gradient is zero during this event, but we note an increase in the surface to deep $\delta^{13} \mathrm{C}$ gradient with one of the heaviest post-carbon shift planktonic $\delta^{13} \mathrm{C}$ values. Thus, part of the increase in carbonate accumulation in Site 704 could be attributed to an increase in surface water productivity during the short glacial time. The decrease in the temperature gradient could be an expression of upwelling of colder bottom water. 
Diatom assemblages indicate a brief period of surface water cooling between 4.75 and $4.68 \mathrm{Ma}$ followed by another major warming event at the base of the Sidufjall Subchron (4.47 Ma). The PFZ was positioned well south of Site 704 during the early Gilbert Chron, and warm surface water prevailed, with the exception of a brief cooling event at 4.66 Ma. Globorotalids dominated the planktonic foraminiferal assemblage (Brunner, this volume) and Dictyocha was consistently present. This interval is correlative with warm surface waters in the Southern Ocean, as implied by silicoflagellates (Ciesielski and Weaver, 1974) and isotopic records (Hodell and Kennett, 1986). It has been suggested that the West Antarctic Ice Sheet was probably absent during this time period, with the Wright and Taylor valleys and the Wilkes and Pensacola basins flooded by the sea (Webb et al., 1984; Prentice et al., in press). In view of preliminary results of Leg 113 from Site 694, such major deglaciation events were probably brief in duration. Major deglaciation events most likely occurred between 5.05 and $4.75 \mathrm{Ma}$ and near the base of the Sidufjall Subchron (4.47 Ma).

\section{Carbon Isotopes}

The late Miocene (Chron C3AR) carbon shift has been previously dated as occurring between 6.58 and $\sim 5.9 \mathrm{Ma}$ in the Pacific, North Atlantic, and Indian oceans (Fig. 5) (Loutit and Kennett, 1979; Keigwin and Shackleton, 1980; Keigwin et al., 1987; Vincent et al., 1980; Hodell and Kennett, 1986). At Site 704 the carbon shift was recorded between 6.4 and $6.0 \mathrm{Ma}$ (Figs. 3-5). Within the same carbon shift at Hole 704B, a slight pause is recorded between 6.3 and 6.12 Ma (250.81$246.6 \mathrm{mbsf}$ ).

In Hole 704B, the onset of the carbon shift is coincident with the initial decrease in carbonate content of the sediments. At Site 281 ( $1500 \mathrm{~m}$ water depth) in the subantarctic southwest Pacific, the carbon shift interval is also associated with lower carbonate content attributed to a dissolution event (Fig. 4; Loutit, 1981). The decrease in $\delta^{13} \mathrm{C}$ values within the carbon shift can be explained partially by an increase in the $\mathrm{CO}_{2}$ content of deep water derived from the oxidation of organic carbon. This increased $\mathrm{CO}_{2}$ would enhance the dissolution of carbonate on the seafloor.

The decrease in carbonate and $\delta^{13} \mathrm{C}$ values at Hole 704B suggests that the residence time of deep water increased and the ventilation rate of the Southern Ocean decreased during the late Miocene between 6.4 and 6.0 Ma. This interpretation is also consistent with the deposition of the Neobrunia ooze indicating suboxic bottom water conditions at Site 701. In fact, detailed correlation by diatoms and magnetostratigraphy between Sites 704 and 701 suggests that the Neobrunia ooze was deposited during the carbon shift interval (Fenner, this volume).

The magnitude of the carbon shift at Site 704 (an average of approximately $0.85 \%$ ) is one of the largest yet reported and is similar to the carbon shift measured in the Indian Ocean (Fig. 5; Vincent et al., 1980). At Site 238, an increase in the sedimentation rate follows the carbon shift, along with an increased abundance of siliceous microfossils. Part of the carbon shift in the equatorial Indian Ocean is due to an increase in fertility (Vincent et al., 1980). This is also the case at Site 704, where the abundance of upwelling and productivity indicators in the diatom assemblages increases after 6.0 Ma.

The ubiquitous occurrence of the Chron 6 carbon shift in both oceanic surface and deep waters implicates a synchronous global change in the $\delta^{13} \mathrm{C}$ of total $\mathrm{CO}_{2}$ of seawater. Some authors have suggested that the carbon shift occurred in response to lowered sea level as a result of Antarctic glaciation (Vincent et al., 1980; Loutit and Keigwin, 1982; Berger and Vincent, 1986). A weakness of this hypothesis noted by Keigwin et al. (1987) is the absence of oxygen isotopic evidence for a glaciation of long-enough duration to cause a "permanent" decrease in $\delta^{13} \mathrm{C}$ values. In Hole 704B, the carbon shift $(6.4-6.0 \mathrm{Ma})$ is associated with a decrease in benthic and planktonic $\delta^{18} \mathrm{O}$ values indicating warming and
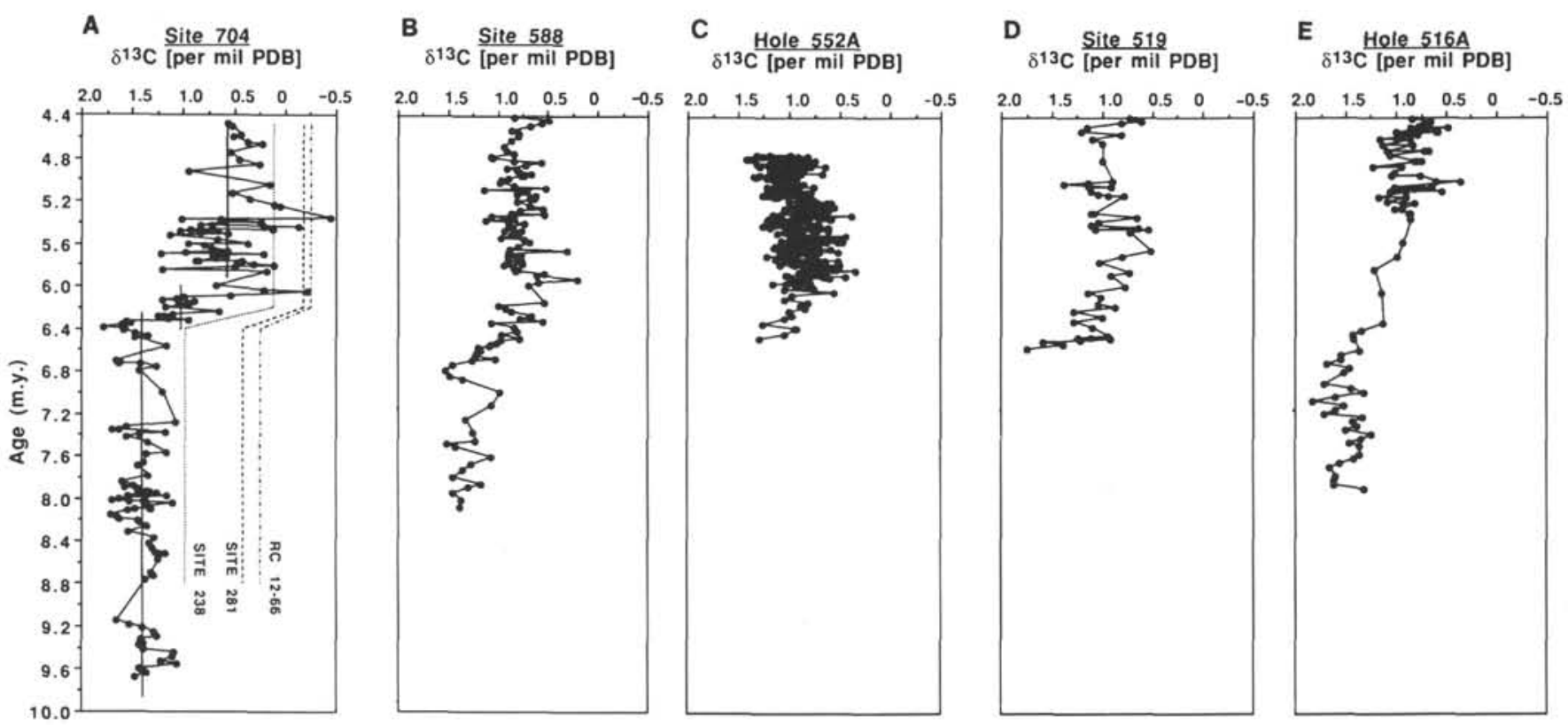

Figure 5. Comparison of the benthic late Miocene carbon shift of Site 704 with other well-defined benthic carbon shifts. A. Comparison of mean pre-, syn-, and post-carbon shift values at Site 704 with those of Site 238 from the Indian Ocean (Vincent et al., 1980), Site 281 from the subantarctic southwest Pacific (Shackleton and Kennett, 1975), and piston core RC 12-66 from the equatorial Pacific (Keigwin and Shackleton, 1980). B. Southwest Pacific Site 588 (Kennett, 1986). C. North Atlantic Hole 552A (Keigwin et al., 1987). D and E. South Atlantic Site 519 and Hole 516A (Hodell and Kennett, 1986). 
interglacial conditions. A decrease in planktonic and benthic $\delta^{18} \mathrm{O}$ values associated with the carbon shift has also been reported from DSDP Site 588 in the southwest Pacific (Fig. 5) (Hodell and Kennett, 1986). Our oxygen isotopic data provide no evidence to support a major ice buildup during the time of the shift which would lead to such a regression. To the contrary, evidence from Hole 704B suggests a warming and a rise in sea level between 6.3 and $6.12 \mathrm{Ma}$.

If the beginning of the carbon shift occurred during a warm interglacial interval, then what was the source of the light carbon? Continental shelves could not have played an important role if the sea level was high. Because the shift occurs in both bottom and surface waters, it cannot be due solely to a change in the ventilation rate of bottom water. The carbon shift was most likely caused by a change in the mass balance of carbon in the ocean, such as the burial rate of organic carbon relative to carbonate carbon in the sediments, or a decrease in the average $\delta^{13} \mathrm{C}$ of riverine bicarbonate (for review see Berger and Vincent, 1986).

Without invoking a sea-level fall, it is possible to decrease the $\delta^{13} \mathrm{C}$ of oceanic bicarbonate by decreasing the burial rate of organic carbon in shelf or deep-sea sediments. For example, tectonic uplift in the circum-Pacific occurred during the latest Miocene because of a rotational change in the motion of the Pacific plate (Barron, 1986a). Tectonic uplift of circumPacific "Monterey-type" basins would have eliminated these basins as a sink for organic carbon (Teng and Gorsline, 1989; Madrid, 1982; Barron, 1986a). Alternatively, the burial rate of organic carbon in the deep sea may have decreased. During the late Miocene, about the time of the carbon shift, the depositional center for biosiliceous sediments moved from the low latitudes to the Southern Ocean (Van Andel, 1975; Leinen, 1979; Brewster, 1980), with an expansion of the PFZ (Kemp et al., 1975; Tucholke et al., 1976). Along with this shift, one might expect the locus of organic carbon deposition in the deep sea to have also shifted toward the Southern Ocean. However, sediments underlying the high-productivity biosiliceous belt of the Southern Ocean do not contain proportionally as high of an amount of organic carbon as do other upwelling regions. Presumably, recycling of nutrients and carbon is highly efficient in the Antarctic, and relatively little carbon is buried in the sediments. A decrease in the rate of organic carbon burial due to increased efficiency of nutrient cycling and carbon regeneration is another potential mechanism for producing the Chron C3AR carbon shift.

\section{CORRELATION BETWEEN THE SOUTHERN OCEAN AND THE MEDITERRANEAN SEA}

A link between the Messinian salinity crisis and climatic/ oceanographic changes has been discussed by numerous authors (Ryan, Hsü, et al., 1973; Ryan et al., 1974; Shackleton and Cita, 1979; Adams et al., 1977; Kennett, 1977; Ciesielski et al., 1982; McKenzie and Oberhänsli, 1985; Hodell et al., 1986; Müller and Hsü, 1987; Keigwin et al., 1987; among others). Recent magnetostratigraphic results from the Mediterranean place the Messinian stage between approximately 6.4 and 4.9 Ma (Channell et al., 1990; Hilgen and Langereis, 1988). Assuming that the Messinian salinity crisis of the Mediterranean Sea had a significant impact on the circulation and also the salt and $\mathrm{Ca}^{2+}$ budget of the ocean, it is probably not coincidental that the interval of low carbonate between 6.4 and $4.8 \mathrm{Ma}$ in Hole 704B is time equivalent, within chronologic error, to the Messinian Stage in the Mediterranean (Fig. 6).

The onset of the lower evaporite deposition (Ryan, Hsü, et al., 1973; Decima and Wezel, 1973) occurred between 5.8 and 5.5 Ma (Gersonde and Schrader, 1984; Müller and Hsü, 1987;
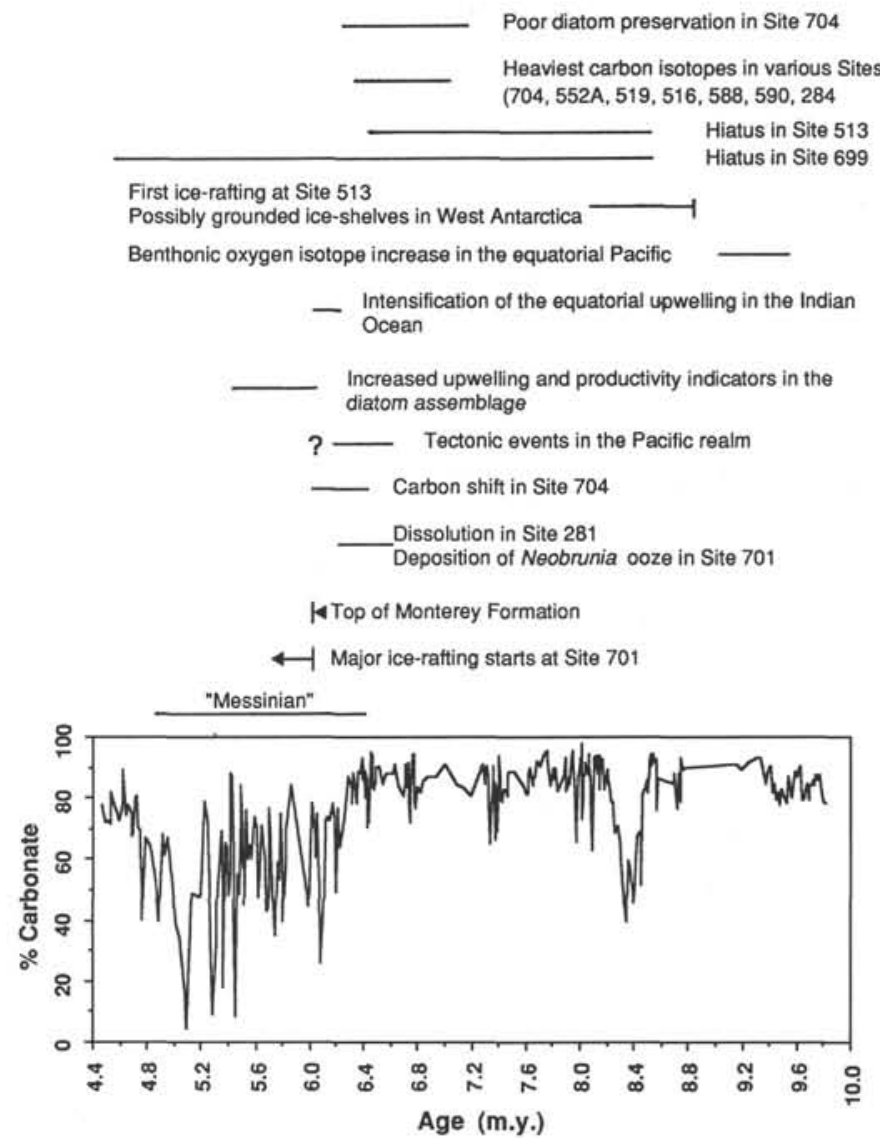

Figure 6. Percent calcium carbonate in the upper Miocene of Hole $704 \mathrm{~B}$ and the temporal distribution of late Miocene depositional, isotopic, and erosional events in the Southern Ocean and elsewhere.

Hodell et al., 1989). In the $600,000-900,000-y r$ interval prior to evaporite deposition (between 6.4 and 5.8-5.5 Ma), pronounced changes occurred within the Mediterranean (McKenzie et al., 1979). For example, evaporite deposition was preceded by the deposition of the Tripoli Formation, which occurs just above the Chron 6 carbon shift (Van der Zwaan and Gudjonsson, 1986; McKenzie et al., 1979). The onset of the Messinian salinity crisis has been traditionally attributed to a worldwide sea-level drop caused by ice buildup on Antarctica that severed the connection between the Atlantic and the Mediterranean (Shackleton and Kennett, 1975; Adams et al., 1977; Berggren and Haq, 1976). Here we attempt to correlate events between the Mediterranean and Southern Ocean to investigate possible linkages between the two.

In northwest Morocco, Hodell et al. (1989) and Benson et al. (in press) documented a reversal in the direction of deep water flow through the Rifian Corridor at $6.3 \mathrm{Ma}$ resulting in an estuarine-type circulation pattern for the Mediterranean and the cessation of Mediterranean Outflow Water (MOW). This reversal in circulation is coincident with the Chron 6 "carbon shift" in Moroccan sequences (Hodell et al., 1989). In the Betic Straits, this event is marked by a change from hemipelagic marls to highly detrital marls and conglomerates (Müller and Hsü, 1987).

The presence of the carbon shift within the Mediterranean Sea (Van der Zwaan and Gudjonsson, 1986), at the western end of the Rifian Corridor (Hodell et al., 1989), and in the Southern Ocean provides a valuable time-stratigraphic horizon for correlating Hole 704B to the Mediterranean. Based 
upon oxygen isotopic evidence from Site 704 and from North Atlantic Hole 552A there is no indication of a significant ice volume buildup or sea-level fall at the time of the carbon shift (Keigwin et al., 1987). Therefore, the restriction between the Mediterranean Sea and the Atlantic Ocean at 6.3 Ma was most likely related to a plate tectonic event between the European and African plates, rather than an eustatic sea-level fall (Hsü et al., 1977; Horvath and Berckhemer, 1982).

There are several mechanisms by which changes in the Mediterranean could have impacted the Southern Ocean and vice versa. One is through the production of MOW and its effect on the formation of NADW, assuming that circulation in the late Miocene was similar to that of the modern one. Today, relatively warm, saline MOW (temperature $=6.5^{\circ} \mathrm{C}$, salinity $=35.4 \%$ oo) exits the Mediterranean at Gibraltar and occupies middle water depths $(\sim 1000 \mathrm{~m})$ off Morocco (Reid, 1978). Reid (1979) proposed that MOW was an important source of salt to the Norwegian-Greenland Sea and to the formation of NADW. The shutoff of MOW during the late Miocene would be expected to alter the salinity field of the middle water depth North Atlantic (Blanc and Duplessy, 1982). Via the teleconnective linkage of NADW production, this salt deficit would be translated to the Southern Ocean. The production and influx of NADW to the Southern Ocean is a major source of heat and salt and continually renews CPDW in the South Atlantic sector (Oppo and Fairbanks, 1987; Gordon, 1971). Wind-driven upwelling of heat and salt, provided by NADW, in the high latitudes of the Southern Hemisphere exerts an important control on basal melting of ice shelves and sea ice in the austral spring (Gordon, 1971; Oppo and Fairbanks, 1987; Crowley and Parkinson, 1988). Thus, changes in the flux of heat and salt transport from the North Atlantic in the past may have significantly influenced the oceanography of the Southern Ocean (Oppo and Fairbanks, 1987).

Weyl (1968) suggested that the salinity distribution of the world ocean has a profound effect on the formation of sea ice in high latitudes and, hence, on climate. Extraction of salt in the Messinian evaporites and cessation of MOW may have altered the salinity distribution in the Southern Ocean and impacted the seasonal formation and melting of sea ice.

At the time of the carbon shift in the Southern Ocean, when MOW production presumably diminished or ceased, a decrease in carbon isotopic values and intense carbonate dissolution occurred in Hole 704B, indicating an older, more corrosive deep water in the Southern Ocean. The deep water in the circum-Antarctic would be expected to show a decrease in $\delta^{13} \mathrm{C}$ values and increased corrosivity if NADW production decreased at 6.3 Ma (Kroopnick, 1985; Oppo and Fairbanks, 1987). In general, the carbon shift interval, in the subantarctic between 6.3 and $6.0 \mathrm{Ma}$, is marked by rapidly fluctuating oceanographic conditions in surface waters that likely included temperature and salinity fluctuations. Diatom and silicoflagellate assemblages and planktonic $\delta^{18} \mathrm{O}$ values indicate brief, yet extreme, warming events in the subantarctic at this time. We hypothesize that this variation was due to the instability (frequent growth and decay) of the West Antarctic Ice Sheet during its initial stage of formation.

It is still a matter of debate whether or not the cessation of MOW had an impact on NADW formation (Blanc and Duplessy, 1982; Johnson, 1982; Keigwin et al., 1987; Zahn et al., 1987; Hodell et al., 1989). Blanc and Duplessy (1982) suggested that the formation of NADW stopped in the latest Miocene based on limited $\delta^{13} \mathrm{C}$ data between the Atlantic and Pacific. Based upon high-resolution carbon isotopic data from DSDP Hole 552A, Keigwin et al. (1987) suggested that the general North Atlantic deep circulation was unaffected by the
Messinian salinity crisis. Intervals of intense carbonate dissolution or hiatuses in the tropical and subtropical Atlantic (Ryan et al., 1974; Thunell, 1981; Shipboard Scientific Party, 1977; Barker et al., 1981) have been attributed to decreased NADW production leading to an older, $\mathrm{CO}_{2}$-enriched bottom water (Johnson, 1982). In Hole 642B in the Norwegian Sea, the late Miocene is marked by periods of carbonate dissolution lasting several hundreds of thousands of years, suggesting intervals of reduced ventilation and diminished production of NADW (Jansen et al., in press). Pulselike changes in production rates of MOW and NADW during the latest Miocene may have contributed to carbonate dissolution and temperaturesalinity instability in the Southern Ocean.

The period of instability in the subantarctic ends with the onset of an intense glaciation period between 5.8 and $5.4 \mathrm{Ma}$. This interval marks a time of ice sheet expansion and sea-level lowering that may have led to the onset of evaporite deposition at 5.5 Ma. The lowermost Gilbert dissolution event between 5.35 and $4.8 \mathrm{Ma}$ is equivalent to the deposition of the upper evaporite unit, which has been magnetically determined to occur entirely within the reversed polarity interval of the Gilbert (Channell et al., in press). This dissolution event represents a shoaling of the lysocline and CCD. It has been proposed that rapid extraction of carbonate and sulfates within the upper evaporites may have briefly altered the carbonate saturation state of the oceans (Thierstein and Berger, 1978; Berger et al., 1981; Thunell et al., 1987). Alternatively, the low-carbonate interval between 6.4 and 4.8 Ma may have been caused by a decrease in the ventilation rate of the deep sea because of diminished production of NADW. Whatever the cause, the early Gilbert dissolution event ended abruptly at the base of the Thvera Subchron at $4.8 \mathrm{Ma}$. This date agrees with most recent estimates for the base of the Zanclean, which marks the termination of the salinity crisis and the return of open-marine conditions in the Mediterranean (Channell et al., 1988; McKenzie et al., 1988; Zijderveld et al., 1986; Hilgen and Langereis, 1988). This flooding event occurs within the warmest period of the early Gilbert (5.05-4.75 Ma) and is likely a consequence of partial deglaciation and eustatic sea-level rise. Another effect on the deep-water production and circulation in the Atlantic might have been the onset of a gradual closure of the Panama Isthmus (Crowley et al., 1989). This event could have intensified NADW production in the early Pliocene even without the presence of MOW.

\section{CONCLUSIONS}

At Site 704, the early to middle late Miocene (9.8-6.4 Ma) was marked by generally stable oceanographic conditions in surface and deep waters. Microfossil productivity was dominated by calcareous nannoplankton and foraminifers in the surface waters north of the Subantarctic Front. An initial brief approach of the subantarctic biosiliceous productivity zone is manifested by a brief carbonate drop to $40 \%$ between 8.45 and 8.2 Ma.

The second major interval between 6.4 and $4.8 \mathrm{Ma}$ is a period of climatic instability, expressed by high-frequency oscillations in carbonate content and planktonic and benthic isotopic values. The reduced carbonate content in the subantarctic is likely related to decreased ventilation of Southern Ocean deep water by NADW as a consequence of the isolation of the Mediterranean during the Messinian (6.4 to 4.9 Ma). The late Miocene Chron C3AR carbon shift $(6.4 \mathrm{Ma})$ of $0.85 \%$ in planktonic and benthic foraminifers dominates the $\delta^{13} \mathrm{C}$ record. The higher resolution benthic record $(6.3-6.12$ Ma) reveals a plateau in carbon values dividing the shift into two increments, one between 6.40 and $6.30 \mathrm{Ma}$ and the second between 6.12 and $6.0 \mathrm{Ma}$. The onset and plateau part of the 
shift occurred during interglacial conditions and is not in response to a lowered sea level induced by increased Antarctic glaciation. Warmest conditions existed at $\sim 6.15 \mathrm{Ma}$ and $\sim 5.8 \mathrm{Ma}$, as revealed by strong decreases in planktonic and benthic $\delta^{18} \mathrm{O}$ values. These events are inferred to partially represent salinity effects caused by brief deglaciations that introduced large volumes of isotopically light meltwater into the subantarctic. The deglaciation event at $\sim 6.15 \mathrm{Ma}$ appears to have been particularly pronounced and is considered to be age equivalent to the deposition of the organic-rich Neobrunia ooze at Site 701, which was under the influence of AABW. Deglaciation in West Antarctica is suggested to have formed a meltwater lid over the Southern Ocean, decreasing or halting the formation of AABW and decreasing the ventilation rate in the deep basins of the South Atlantic. Consequently, organicrich sediments were deposited at Sites 520 and 701 . At the end of the second part of the carbon shift, a major period of upwelling commenced (6.0-5.4 Ma) as the Subantarctic Front migrated over the site, and surface water rapidly cooled.

The absence of proxy data for a sea-level drop during the late Miocene carbon shift suggests a link to a decreased burial rate of organic carbon in shelf or deep-sea sediments. Two plausible mechanisms are (1) decreased sequestering of organic carbon in Monterey-type basins in the circum-Pacific and/or (2) a decrease in carbon burial in the deep sea related to shifting of the depositional center of biosiliceous and organic carbon sedimentation from the low latitudes to the Southern Ocean. The more efficient Southern Ocean nutrient recycling and the proportionately lower organic carbon content of its biosiliceous sediments might account for part of the permanent decrease in $\delta^{13} \mathrm{C}$ of oceanic bicarbonate during the late Miocene.

The Messinian Stage in the Mediterranean indicates that it is temporally equivalent to the interval of low carbonate content in Hole 704B between 6.4 and $4.8 \mathrm{Ma}$. Comparison of Messinian events with Site 704 and North Atlantic Hole 552A supports the interpretation that plate tectonic interactions between the African and European plates are the cause for restriction of the Mediterranean at $6.3 \mathrm{Ma}$, rather than the result of eustatic sea-level fall. Pulselike changes in production rates of MOW and NADW during the Messinian may have contributed to Southern Ocean carbonate dissolution and temperature-salinity instability. The onset of Mediterranean evaporite deposition between 5.8 and $5.5 \mathrm{Ma}$ appears to be more directly related to a glacioeustatic event because benthic $\delta^{18} \mathrm{O}$ values at Hole 704B and other sites increase at this time, thereby marking a prolonged period of predominantly glacial conditions that lasted until 5.4 Ma. The deposition of the upper evaporites during the earliest Gilbert Chron is associated with a severe dissolution event in the Southern Ocean, and elsewhere, suggesting that carbonate extraction in evaporitic deposits may have temporarily altered the alkalinity balance of the oceans. The flooding event that terminated the Messinian salinity crisis occurred during an earliest Gilbert pronounced interglacial period (5.05-4.75 Ma) and was apparently caused by partial deglaciation and eustatic sealevel rise.

\section{ACKNOWLEDGMENTS}

We thank the crew and scientific party of ODP Leg 114 for their logistic and scientific support, and the ODP for samples. DWM is grateful to the Swiss National Science Foundation, who supported the participation on this cruise. Discussions with G. Mead about Southern Ocean paleoceanography were helpful. Anonymous reviews were constructive and are acknowledged. S. Case-Ciesielski is thanked for editorial and drafting assistance. This research was supported by U.S. Science Program (USSAC) Grant \#20114 to DAH and National Science Foundation (NSF) Grant \#DPP-8717854 to $\mathrm{PFC}$ and DAH.

\section{REFERENCES}

Adams, C. G., Benson, R. H., Kidd, R. B., Ryan, W. B. F., and Wright, R. C., 1977. The Messinian salinity crisis and evidence of late Miocene eustatic changes in the world ocean. Nature, 269:383-386.

Backman, J., Schneider, D. A., Rio, D., and Okada, H., in press. Neogene low-latitude magnetostratigraphy from ODP Site 710 and revised age estimates of Miocene nannofossil datum events. In Duncan, R. A., Backman, J., et al., Proc. ODP, Sci. Results, 115: College Station, TX (Ocean Drilling Program).

Baldauf, J. G., 1985. A high resolution late Miocene-Pliocene diatom biostratigraphy for the eastern equatorial Pacific. In Mayer, L., Theyer, F., Thomas, E., et al., Init. Repts. DSDP, 85: Washington (U.S. Govt. Printing Office), 457-475.

Barker, P. F., Carlson, R. L., Johnson, D. A., Cepek, P., Coulbourn, W., Gamboa, L. A., Hamilton, N., Melo, U., Pujol, C., Shor, A. N., Suzyumov, A. E., Tjalsma, L. R. C., Walton, W. H., and Weiss, W., 1981. Southwest Atlantic circulation and Rio Grande Rise tectonics. Geol. Soc. Am. Bull., 92:294-309.

Barker, P. F., Kennett, J. P., et al., 1988. Proc. ODP, Init. Repts., 113: College Station, TX (Ocean Drilling Program).

Barron, J. A., 1985. Late Eocene to Holocene diatom biostratigraphy of the equatorial Pacific Ocean, Deep Sea Drilling Project Leg 85. In Mayer, L., Theyer, F., Thomas, E., et al., Init. Repts. DSDP, 85: Washington (U.S. Govt. Printing Office), 413-456.

1986a. Paleoceanographic and tectonic controls on deposition of the Monterey Formation and related siliceous rocks in California. Palaeogeogr., Palaeoclimatol., Palaeoecol., 53:27-54. 1986b. Updated diatom biostratigraphy for the Monterey Formation of California. In Casey, R., and Barron, J. (Eds.), Siliceous Microfossil and Microplankton Studies of the Monterey Formation and Modern Analogs. Soc. Econ. Paleontol. Mineral. Pacific Sec. Spec. Publ., 45:115-119.

Barron, J. A., Keller, G., and Dunn, D. A., 1985a. A multiple microfossil biochronology for the Miocene. In Kennett, J. P. (Ed.), The Miocene Ocean: Paleoceanography and Biogeography. Mem. Geol. Soc. Am., 163:21-36.

Barron, J., Nigrini, C. A., Pujos, A., Saito, T., Thayer, F., Thomas, E., and Weinrich, N., 1985. Synthesis of biostratigraphy, central equatorial Pacific, Deep Sea Drilling Project Leg 85: refinement of Oligocene to Quaternary biochronology. In Mayer, L., Thayer, F., Thomas, E., et al., Init. Repts. DSDP, 85: Washington (U.S. Govt. Printing Office), 905-934.

Benson, R. H., Rakic-El Bied, K., and Bonaduce, G., in press. An important water-mass reversal in the Rifian Portal (Morocco) at the Tortonian-Messinian boundary. Cont. Paleoclimatol.

Berger, W. H., and Vincent, E., 1986. Deep-sea carbonates: reading the carbon-isotope signal. Geol. Rundsch., 75:249-269.

Berger, W. H., Vincent, E., and Thierstein, H. R., 1981. The deep-sea record: major steps in Cenozoic ocean evolution. In Warme, J. E., Douglas, R. G., and Winterer, E. L. (Eds.), The Deep Sea Drilling Project: A Decade of Progress. Soc. Econ. Paleontol. Mineral. Spec. Publ., 32:489-504.

Berggren, W. A., and Haq, B. U., 1976. The Andalusian Stage (late Miocene): biostratigraphy, biochronology and paleoecology. Palaeogeogr., Palaeoclimatol., Palaeoecol., 20:67-129.

Berggren, W. A., Kent, D. V., and Van Couvering, J. A., 1985. The Neogene: Part 2, Neogene geochronology and chronostratigraphy. In Snelling, N. J. (Ed.), Chronology of the Geological Record: Geol. Soc. London Mem., 10:211-260.

Blanc, P.-L., and Duplessy, J.-C., 1982. The deep water circulation during the Neogene and the impact of the Messinian salinity crisis. Deep-Sea Res., Part A, 29:1391-1414.

Brewster, N. A., 1980. Cenozoic biogenic silica sedimentation in the Antarctic Ocean, based on two Deep Sea Drilling Project sites. Geol. Soc. Am. Bull., 91:337-347.

Burckle, L. H., 1972. Late Cenozoic planktonic diatom zones from the eastern equatorial Pacific. Nova Hedwigia, 39:217-246. 
1978. Early Miocene to Pliocene diatom datum levels for the equatorial Pacific. Proc. Second Working Group Mtg., Biostratig. Datum-Planes Pacific Neogene, IGCP Project 114 (Bandung, Indonesia, May 30-June 1, 1977). Spec. Publ. Geol. Res. Dev. Ctr., 1:25-44.

Channell, J.E.T., Rio, D., and Thunell, R. C., 1988. MiocenePliocene boundary magnetostratigraphy at Capo Spartivento, Calabria, Italy. Geology, 16:1096-1099.

Channell, J.E.T., Torii, M., and Hawthorne, T., 1990. Magnetostratigraphy of sediments recovered at Sites $650,651,652$, and 654 (Leg 107 Tyrrhenian Sea). In Kastens, K. A., Mascle, J., et al., Proc. ODP, Sci. Results, 107: College Station, TX (Ocean Drilling Program), 335-346.

Chappell, J., and Shackleton, N. J., 1986. Oxygen isotopes and sea level. Nature, 324:137-140.

Charles, C. D., and Fairbanks, R. G., in press. Glacial to interglacial changes in the stable isotopic composition of surface and deep waters in the Southern Ocean. In Geologic History of the Polar Oceans: Antarctic versus Arctic. NATO ASI Series.

Ciesielski, P. F., 1983. The Neogene and Quaternary diatom biostratigraphy of subantarctic sediments, Deep Sea Drilling Project Leg 71. In Ludwig, W. J., Krasheninnikov, V. A., et al., Init. Repts. DSDP, 71: Washington (U.S. Govt. Printing Office), 625-691.

Ciesielski, P. F., Kristoffersen, Y., et al., 1988. Proc. ODP, Init. Repts., 114: College Station, TX (Ocean Drilling Program).

Ciesielski, P. F., Ledbetter, M. T., and Ellwood, B. B., 1982. The development of Antarctic glaciation and the Neogene paleoenvironment of the Maurice Ewing Bank. Mar. Geol., 46:1-51.

Ciesielski, P. F., and Weaver, F. M., 1974. Early Pliocene temperature changes in the Antarctic Seas. Geology, 12:511-515.

, 1983. Neogene and Quaternary paleoenvironmental history of Deep Sea Drilling Leg 71 sediments, southwest Atlantic Ocean. In Ludwig, W. J., Krasheninnikov, V. A., et al., Init. Repts. DSDP, 71: Washington (U.S. Govt. Printing Office), 461-477.

Crowley, T. J., Maier-Reimer, E., and Mikolajewicz, U., 1989. Effect of an open Central American Isthmus on North Atlantic Deep Water production. Terra: Abstracts 3rd Inter. Conf. Paleoceanogr., Cambridge, 1:12. (Abstract)

Crowley, T. J., and Parkinson, C. L., 1988. Late Pleistocene variations in Antarctic sea ice. II: Effect of interhemispheric deep ocean heat exchange. Cli. Dyn., 3:93-103.

Decima, A., and Wezel, E. C., 1973. Late Miocene evaporites of the central Sicilian basin, Italy. In Ryan, W.B.F., Hsü, K. J., et al., Init. Repts. DSDP, 13: Washington (U.S. Govt. Printing Office), 1234-1240.

Dumont, M. P., Baldauf, J. G., and Barron, J. A., 1986. Thalassiosira praeoestrupii-a new diatom species for recognizing the Miocene/ Pliocene Epoch boundary in coastal California. Micropaleontology, 32:372-377.

Dunn, D. A., Moore, T. C., and Keigwin, L. D., 1981. Atlantic-type carbonate stratigraphy in the late Miocene Pacific. Nature, 291: 225-227.

Duplessy, J.-C., Labery, L. L., and Shackleton, N. J., 1985. The oxygen isotope record of benthic foraminifera: effects of deep water temperature and ice volume changes. EOS, Trans. Am. Geophys. Union, 66:292.

Gersonde, R., and Schrader, H., 1984. Marine planktic diatom correlation of lower Messinian deposits in the western Mediterranean. Mar. Micropaleontol., 9:93-110.

Gombos, A. M., Jr., 1984. Late Neogene diatoms and diatom oozes in the central South Atlantic. In Hsü, K. J., La Brecque, J. L., et al., Init. Repts. DSDP, 73: Washington (U.S. Govt. Printing Office), 487-494.

Gordon, A. L., 1971. Oceanography in Antarctic waters. In Reid, J. L. (Ed.), Antarctic Oceanology I. Am. Geophys. Union, Antarctic Res. Ser., 15:169-203.

Hilgen, F. J., and Langereis, C. G., 1988. The age of the MiocenePliocene boundary in the Capo Rossello area (Sicily). Earth Planet. Sci. Lett., 91:214-222.

Hodell, D. A., Benson, R. H., Kennett, J. P., and El Bied Rakic, K., 1989. Stable isotope stratigraphy of late Miocene-early Pliocene sequences in northwest Morocco: the Bou Regreg section. Paleoceanography, 3:467-482.
Hodell, D. A., Elmstrom, K. M., and Kennett, J. P., 1986. Latest Miocene benthic $\delta^{18} \mathrm{O}$ changes, global ice volume, sea level, and the "Messinian salinity crisis." Nature, 320:411-414.

Hodell, D. A., and Kennett, J. P., 1986. Late Miocene-early Pliocene stratigraphy and paleoceanography of the South Atlantic and southwest Pacific Oceans: a synthesis. Paleoceanography, 1:285-311.

Horvath, F., and Berckhemer, H., 1982. Mediterranean backarc basins. In Berckhemer, H., and Hsü, K. J. (Eds.), Alpine Mediterranean Geodynamics. Geodynamics Ser., Am. Geophys. Union, 7:141-173.

Hsü, K. J., Montadert, L., Bernoulli, D., Cita, M. B., Erickson, A., Garrison, R. E., Kidd, R. B., Melières, F., Müller, C., and Wright, R., 1977. History of the Mediterranean salinity crisis. In Hsü, K. J., Montadert, L., et al., Init. Repts. DSDP, 42 (Pt. 1): Washington (U.S. Govt. Printing Office), 1053-1078.

Hsü, K. J., and Wright, R., 1985. History of calcite dissolution of the South Atlantic Ocean. In Hsü, K. J., and Weissert, H. (Eds.), South Atlantic Paleoceanography: Cambridge (Cambridge Univ. Press), 149-196.

Jansen, E., Sjoholm, J., Bleil, U., and Erichsen, J. A., in press. Neogene and Pleistocene glaciations in the Northern Hemisphere and Miocene-Pliocene global ice volume fluctuations: evidence from the Norwegian Sea. In Geologic History of the Polar Oceans: Arctic versus Antarctic. NATO ASI Series.

Johnson, D. A., 1982. Abyssal teleconnections: interactive dynamics of the deep ocean circulation. Palaeogeogr., Palaeoclimatol., Palaeoecol., 38:93-128.

Johnson, D. A., and Wick, B. J., 1982. Precision of correlation of radiolarian datum levels in the middle Miocene equatorial Pacific. Micropaleontology, 28:1-30.

Keigwin, L. D., Aubry, M.-P., and Kent, D. V., 1987. North Atlantic late Miocene stable-isotope stratigraphy, biostratigraphy, and magnetostratigraphy. In Ruddiman, W. F., Kidd, R. B., et al., Init. Repts. DSDP, 94: Washington (U.S. Govt. Printing Office), 935-963.

Keigwin, L. D., Jr., and Shackleton, N. J., 1980. Uppermost Miocene carbon isotope stratigraphy of a piston core in the equatorial Pacific. Nature, 284:613-614.

Kemp, E. M., Frakes, L. A., and Hayes, D. A., 1975. Paleoclimatic significance of diachronous biogenic facies, Leg 28. In Hayes, D. E., Frakes, L. A., et al., Init. Repts. DSDP, 28: Washington (U.S. Govt. Printing Office), 909-917.

Kennett, J. P., 1977. Cenozoic evolution of Antarctic glaciation, the circum-Antarctic Ocean, and their impact on global paleoceanography. J. Geophys. Res., 82:3843-3860.

1986. Miocene to early Pliocene oxygen and carbon isotope stratigraphy of the southwest Pacific, DSDP Leg 90. In Kennett, J. P., von der Borch, C. C., et al., Init. Repts. DSDP, 90: Washington (U.S. Govt. Printing Office), 1383-1411.

Kroopnick, P., 1985. The distribution of carbon-13 in the world oceans. Deep-Sea Res., Part A, 32:57-84.

Labeyrie, L., Pichon, J.-J., Labracherie, M., Ippolito, P., Duprat, J., and Duplessy, J. C., 1986. Melting history of Antarctica during the past 60,000 years. Nature, 322:701-706.

Leinen, M., 1979. Biogenic silica accumulation in the central equatorial Pacific and its implication for Cenozoic paleoceanography. Geol. Soc. Am. Bull., 90:801-803.

Loutit, T. S., 1981. Late Miocene paleoclimatology: subantarctic water mass, southwest Pacific. Mar. Micropaleontol., 6:1-27.

Loutit, T. S., and Keigwin, L. D., Jr., 1982. Stable isotopic evidence for latest Miocene sea level fall in the Mediterranean region. Nature, 300:163-166.

Loutit, T. S., and Kennett, J. P., 1979. Application of carbon isotope stratigraphy to late Miocene shallow marine sediments, New Zealand. Science, 204:1196-1199.

Ludwig, W. J., Krasheninnikov, V. A., et al., 1983. Init. Repts. DSDP, 71: Washington (U.S. Govt. Printing Office).

Lutjeharms, J.R.E., 1985. Location of frontal systems between Africa and Antarctica: some preliminary results. Deep-Sea Res., Part A, 32:1499-1509.

Madrid, V. M., 1982. Magnetostratigraphy of the late Neogene Purisima Formation, Santa Cruz County, California [thesis]. Univ. of California, Davis. 
McKenzie, J. A., Hodell, D. A., Mueller, P. A., and Müller, D. W., 1988. Application of strontium isotopes to late Miocene-early Pliocene stratigraphy. Geology, 16:1022-1025.

McKenzie, J. A., Jenkyns, H. C., and Bennet, G., 1979. Stable isotope study of the cyclic diatomite-claystones from the Tripoli Formation, Sicily: a prelude to the Messinian salinity crisis. Palaeogeogr., Palaeoclimatol., Palaeoecol., 29:125-141.

McKenzie, J. A., and Oberhänsli, H., 1985. Paleoceanographic expressions of the Messinian salinity crisis. In Hsü, K. J., and Weissert, H. (Eds.), South Atlantic Paleoceanography: Cambridge (Cambridge Univ. Press), 99-123.

Mercer, J. H., 1978. Glacial development and temperature trends in the Antarctic and in South America. In Van Zinderen Bakker, E. M. (Ed.), Antarctic Glacial History and World Paleoenvironments: Rotterdam (Balkema), 73-93.

Müller, D. W., and Hsü, K. J., 1987. Event stratigraphy and paleoceanography in the Fortuna Basin (southeast Spain): a scenario for the Messinian salinity crisis. Paleoceanography, 2:679-696.

Oppo, D. W., and Fairbanks, R. G., 1987. Variability in the deep and intermediate water circulation of the Atlantic Ocean during the past 25,000 years: Northern Hemisphere modulation of the Southern Ocean. Earth Planet. Sci. Lett., 86:1-15.

Pisias, N. G., and Prell, W. L., 1985. High resolution carbonate records from the hydraulic piston cored section of Site 572. In Mayer, L., Thayer, F., Thomas, E., et al., Init. Repts. DSDP, 85: Washington (U.S. Govt. Printing Office), 711-722.

Prentice, M. L., Denton, G. H., Bockheim, J. G., Wilson, S. C., Burckle, L. H., Hodell, D. A., and Kellogg, D. E., in press. Surficial geology in Write Valley, Antarctica: implications for Neogene Antarctic glacial history. Geol. Soc. Am. Bull.,

Reid, J. L., 1978. On the middepth circulation and salinity field in the North Atlantic Ocean. J. Geophys. Res., 83:5063-5067.

1979. On the contribution of the Mediterranean Sea outflow to the Norwegian-Greenland Sea. Deep-Sea Res., Part A, 26:1791.

Ryan, W.B.F., Cita, M. B., Rawson, M. D., Burckle, L. H., and Saito, T., 1974. A paleomagnetic assignment of Neogene stage boundaries and the development of isochronous datum planes between the Mediterranean, the Pacific and Indian oceans in order to investigate the response of the world ocean to the Mediterranean "salinity crisis." Riv. Ital. Paleont., 80:631-688.

Ryan, W.B.F., Hsü, K. J., et al., 1973. Init. Repts. DSDP, 13: Washington (U.S. Govt. Printing Office).

Shackleton, N. J., 1982. The deep-sea sediment record of climate variability. Prog. Oceanogr., 11:199-218.

Shackleton, N. J., and Cita, M. B., 1979. Oxygen and carbon isotope stratigraphy of benthic foraminifers at Site 397: detailed history of climatic change during the late Neogene. In von Rad, U., Ryan, W.B.F., et al., Init. Repts. DSDP, 47: Washington (U.S. Govt. Printing Office), 433-445.

Shackleton, N. J., Hall, M. A., and Boersma, A., 1984. Oxygen and carbon isotope data from Leg 74 foraminifers. In Hsü, K. J., La Brecque, J. L., et al., Init. Repts. DSDP, 74: Washington (U.S. Govt. Printing Office), 599-612.

Shackleton, N. J., and Kennett, J. P., 1975. Late Cenozoic oxygen and carbon isotopic changes at DSDP Site 284: implications for glacial history of the Northern Hemisphere and Antarctica. In Kennett, J. P., Houtz, R. E., et al., Init. Repts. DSDP, 29: Washington (U.S. Govt. Printing Office), 801-807.

Shipboard Scientific Party, 1977. Site 357: Rio Grande Rise. In Perch-Nielsen, K., Supko, P. R., et al., Init. Repts. DSDP, 39: Washington (U.S. Govt. Printing Office), 231-327.
Teng, L. S., and Gorsline, D. S., 1989. Late Cenozoic sedimentation in California Continental Borderland basins as revealed by seismic facies analysis. Geol. Soc. Am. Bull., 101:27-41.

Theyer, F., and Hammond, S. R., 1974. Paleomagnetic polarity sequence and radiolarian zones, Brunhes to Epoch 20. Earth Planet. Sci. Lett., 22:307-319.

Theyer, F., Mato, C. Y., and Hammond, S. R., 1978. Paleomagnetic and geochronologic calibration of latest Oligocene to Pliocene radiolarian events, equatorial Pacific. Mar. Micropaleontol., 3:377-395.

Thierstein, H. R., and Berger, W. H., 1978. Injection events in ocean history. Nature, 276:461-466.

Thunell, R. C., 1981. Late Miocene-early Pliocene planktonic foraminiferal biostratigraphy and paleoceanography of low-latitude marine sequences. Mar. Micropaleontol., 6:71-90.

Thunell, R. C., Williams, D. F., and Howell, M., 1987. AtlanticMediterranean water exchange during the late Neogene. Paleoceanography, 2:661-678.

Tucholke, B. E., Hollister, C. D., Weaver, F. M, and Vennum, W. R., 1976. Continental rise and abyssal plain sedimentation in the southeast Pacific basin, Leg 35. In Hollister, C. D., Craddock, C., et al., Init. Repts. DSDP, 35: Washington (U.S. Govt. Printing Office), 359-400.

Van Andel, T. H., 1975. Mesozoic-Cenozoic calcite compensation depth and the global distribution of carbonate sediments. Earth Planet. Sci. Lett., 26:187-194.

Van der Zwaan, G. J., and Gudjonsson, L., 1986. Middle MiocenePliocene stable isotope stratigraphy and paleoceanography of the Mediterranean. Mar. Micropaleontol., 10:71-90.

Vincent, E., Kilingley, J. S., and Berger, W. H., 1980. The Magnetic Epoch 6 carbon shift: a change in the ocean's ${ }^{13} \mathrm{C} /{ }^{12} \mathrm{C}$ ratio 6.2 million years ago. Mar. Micropaleontol., 5:185-203.

Weaver, F. M., 1983. Cenozoic radiolarians from the southwest Atlantic, Falkland Plateau region, Deep Sea Drilling Project Leg 71. In Ludwig, W. J., Krasheninnikov, V. A., et al., Init. Repts. DSDP, 71: Washington (U.S. Govt. Printing Office), 667-686.

Webb, P. N., Harwood, D. M., McKelvey, B. C., Mercer, J. N., and Stott, L. D., 1984. Cenozoic marine sedimentation and ice-volume variation on the East Antarctic craton. Geology, 12:287-291.

Weyl, P. K., 1968. The role of the oceans in climate change: a theory of the ice ages. Met. Monogr., 8:37-62.

Wise, S. W., Gombos, A. M., and Muza, J. P., 1985. Cenozoic evolution of polar water masses, southwest Atlantic Ocean. In Hsü, K. J., and Weissert, H. J. (Eds.), South Atlantic Paleoceanography: Cambridge (Cambridge Univ. Press), 283-324.

Woodruff, F., Savin, S. M., and Douglas, R. G., 1980. Biological fractionation of oxygen and carbon isotopes by Recent benthic foraminifera. Mar. Micropaleontol., 5:3-11.

Zahn, R., Sarnthein, M., and Erlenkeuser, H., 1987. Benthic isotope evidence for changes of the Mediterranean outflow during the late Quaternary. Paleoceanography, 2:543-559.

Zijderveld, J.D.A., Zachariasses, J. W., Verhallen, P.J.J.M., and Hilgen, F. J., 1986. The age of the Miocene-Pliocene boundary. Newsl. Stratigr., 16:169-181.

Date of initial receipt: 17 May 1989

Date of acceptance: 27 October 1989

Ms 114B-176 